\title{
Un fardo funerario del Horizonte Tardío del sitio Rinconada Alta, valle del Rímac
}

Un fardeau funéraire de l'Horizon Récent du site de Rinconada Alta, vallée du Rímac

A Late Horizon fardo dating from Rinconada Alta, Rimac valley

Mary Frame, Daniel Guerrero Zevallos, María Carmen Vega Dulanto y Patricia Landa Cragg

\section{(2) OpenEdition}

Journals

Edición electrónica

URL: http://journals.openedition.org/bifea/5377

DOI: $10.4000 /$ bifea.5377

ISSN: 2076-5827

Editor

Institut Français d'Études Andines

Edición impresa

Fecha de publicación: 1 diciembre 2004

Paginación: 815-860

ISSN: 0303-7495

Referencia electrónica

Mary Frame, Daniel Guerrero Zevallos, María Carmen Vega Dulanto y Patricia Landa Cragg, « Un fardo funerario del Horizonte Tardío del sitio Rinconada Alta, valle del Rímac », Bulletin de l'Institut français d'études andines [En línea], 33 (3) | 2004, Publicado el 08 diciembre 2004, consultado el 01 diciembre 2020. URL : http://journals.openedition.org/bifea/5377 ; DOI : https://doi.org/10.4000/bifea.5377

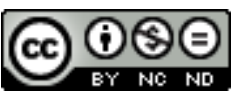

Les contenus du Bulletin de l'Institut français d'études andines sont mis à disposition selon les termes de la licence Creative Commons Attribution - Pas d'Utilisation Commerciale - Pas de Modification 4.0 International. 


\title{
UN FARDO FUNERARIO DEL HORIZONTE TARDÍO DEL SITIO RINCONADA ALTA, VALLE DEL RIMAC
}

\author{
Mary FRAME *, Daniel GUERRERO ZEVALLOS **, María del Carmen \\ VEGA DULANTO ${ }^{* * *}$, Patricia LANDA CRAGG ${ }^{\text {***** }}$
}

\section{Resumen}

Este artículo informa sobre el desenfardelamiento de un fardo funerario costeño que data de la época Inca. El fardo, el cual fue excavado en el sitio de Rinconada Alta, ubicado en el valle del Rímac, abunda en indumentaria y accesorios textiles, brindándonos la oportunidad de examinar un conjunto de textiles asociados a un solo hombre. Se han identificado tanto los tipos de indumentaria Inca como los tipos costeños, aprovechando para ello los estudios recientes sobre textiles Inca e Inca provincial. Las informaciones etnohistóricas sobre la producción y distribución de la indumentaria han sido relacionadas en cuanto sea posible con los textiles arqueológicos del fardo. Se han hecho comparaciones con otros entierros costeños de la misma época para determinar el prestigio relativo de los objetos encontrados dentro del envoltorio funerario. Por medio de los estudios arqueológicos, etnohistóricos y técnicos ya disponibles, se puede deducir a través de los textiles algo acerca del estatus del hombre enterrado en Rinconada Alta y los papeles que desempeñaba durante la vida.

La configuración del fardo y la disposición espacial de los artículos no textiles están también documentadas. Los tipos de ofrendas y su ubicación en el fardo indican que mientras algunas costumbres mortuorias podrían haber sido locales, otras eran prevalentes en la costa del Perú durante una época larga.

Palabras claves: Costa central, fardo funerario, textiles, Horizonte tardío.

\section{UN FARDEAU FUNÉRAIRE DE L'HORIZON RÉCENT DU SITE DE RINCONADA ALTA, VALLÉE DU RÍMAC}

\section{Résumé}

Cet article porte sur l'ouverure d'un fardeau funéraire originaire de la côte et datant de l'époque Inca. Le fardeau, trouvé sur le site de Rinconada Alta, vallée du Rímac, est particulièrement riche en vêtements et accesoires textiles et nous permet d'examiner un ensemble de tissus

*Especialista en textiles, Proyecto Rinconada Alta. E-mail: framem@ @otmail.com

** Arqueólogo y Director, Proyecto Rinconada Alta. E-mail: dgz@terra.com.pe

*** Arqueóloga y especialista en restos humanos, Proyecto Rinconada Alta. E-mail: maricarmenvega@ixp.net

***** Conservadora textil, Proyecto Rinconada Alta. E-mail: planda55@yahoo.com 
associés à un seul homme. Aussi bien les vêtements Incas que côtiers ont été identifiés grâce à des études récentes sur les textiles de l'époque Inca et Inca provincial.L'information ethnohistorique sur la production et la distribution des vêtements a été comparée, dans la mesure du possible, avec les textiles trouvés dans le fardeau. Des comparaisons ont été faites avec d'autres enterrements de la côte de la même époque pour déterminer le niveau de prestige des objets trouvés dans le fardeau. On peut déduire des études arquéologiques, ethnohistoriques et des techniques disponibles sur les textiles le status et les rôles joués au cours de sa vie par l'homme trouvé à Rinconada Alta.

L'information est suffisante sur la configuration du fardeau et la disposition dans l'espace des objets non textiles. Les types d'offrandes et leur disposition dans le fardeau nous font penser que, tandis que certaines coutûmes mortuaires furent locales, d'autres ont été plus largement pratiquées sur la côte du Pérou pendant longtemps.

Mots clés Côte centrale, fardeau funéraire, textiles, Horizon Récent.

\title{
A LATE HORIZON FARDO DATING FROM RINCONADA ALTA, RIMAC VALLEY
}

\begin{abstract}
This article documents the unwrapping of a coastal fardo dating to the Inca period. The fardo, excavated at Rinconada Alta in the Rimac Valley, is particularly rich in garments and textile accessories, and provides the opportunity for examining the suite of textiles associated with one man. Garment types, both Inca and coastal, are identified using recent studies of Inca and Inca-provincial textiles. Ethnohistoric information on Inca production and distribution of cloth is linked where possible to the archaeological textiles in the fardo. Comparisons with other coastal burials of this period are made to assess the relative prestige of the objects in the fardo. Using the archaeological, ethnohistoric, and technical studies now available, inferences can be drawn from the textiles regarding the status and roles during life of the man buried at Rinconada Alta.

The configuration of the fardo and the spatial disposition of non-textile items are also documented. The types of offerings and their placement in the fardo suggest that, while some mortuary customs may have been local, others were widely practiced on the coast of Peru over long periods of time.
\end{abstract}

Key words: Central coast, funerary bundle, textiles, Late Horizon.

El conjunto de artículos que le acompañan al difunto en el rito mortuorio peruano puede arrojar una luz tenue sobre muchos aspectos de la vida antigua, por ejemplo, las creencias y rituales de la comunidad, la categoría, oficio y aptitudes del individuo, y hasta las interacciones sociopolíticas que rodeaban al enterrado durante la vida. Un hombre que vivía en las afueras de Lima, hace más o menos 500 años, fue desenterrado durante una temporada de rescate arqueológico en el sitio de Rinconada Alta en 1999. Se puede deducir algo sobre su vida y la época en que vivía a partir del tratamiento funerario que recibió por parte de su familia y la comunidad. Su fardo o envoltorio funerario es a la vez típico de las prácticas de enterramiento de la región, y es un reflejo personal de él como individuo en un momento determinado de la historia. 
Hay dos perspectivas teóricas opuestas sobre la arqueología mortuoria, las cuales han sido resumidas por Brown (1995: 392) y que son pertinentes para nuestras observaciones sobre el fardo. La primera perspectiva parte del principio a menudo citado de que el tratamiento en la muerte está determinado por el estatus pasado del personaje como individuo vivo. La segunda posición dice que los difuntos son tratados de acuerdo con las necesidades y deseos de los vivos. La primera perspectiva concuerda con muchas de las inferencias esbozadas a partir del análisis de los textiles, es decir que la ropa y los accesorios reflejan el estatus y roles del hombre durante su vida. La segunda perspectiva sirve para examinar la configuración del fardo y la presencia de ofrendas repetidas y la ubicación de estas dentro del envoltorio.

El fardo de forma ovaloide fue armado mediante muchas capas (Fig. 1), como los envoltorios funerarios de otros sitios en muchas épocas. Unas ofrendas como valvas de spondylus, maíz rojo, hojas de coca y fibras hiladas fueron dispuestas entre las capas de tela y fibra del fardo, y una pequeña pieza de metal martillado fue colocada en la boca del difunto. Estas ofrendas se repiten en los entierros costeños (Cock, 2002; Eeckhout, 2002; Menzel, 1977; Ravines \& Stothert, 1976; Stothert, 1979; Uhle, 1991[1903]), lo cual implica que algunos de los actos celebrados en la preparacion del difunto para su entierro fueron dictados por rituales duraderos y una red de creencias que tal vez vinculaban a los antepasados con conceptos de fertilidad (Salomon, 1995: 324-28).

Por otro lado, la indumentaria, los accesorios y las armas indican algo sobre los papeles que desempeñaba el individuo en la sociedad, la categoría que ocupaba entre los habitantes de la Costa Central y su posición dentro de una jerarquía más amplia. La variedad que se nota entre los textiles del fardo también nos da un punto de partida para deducir algo sobre la interacción sociopolítica en la Costa Central en aquella época.

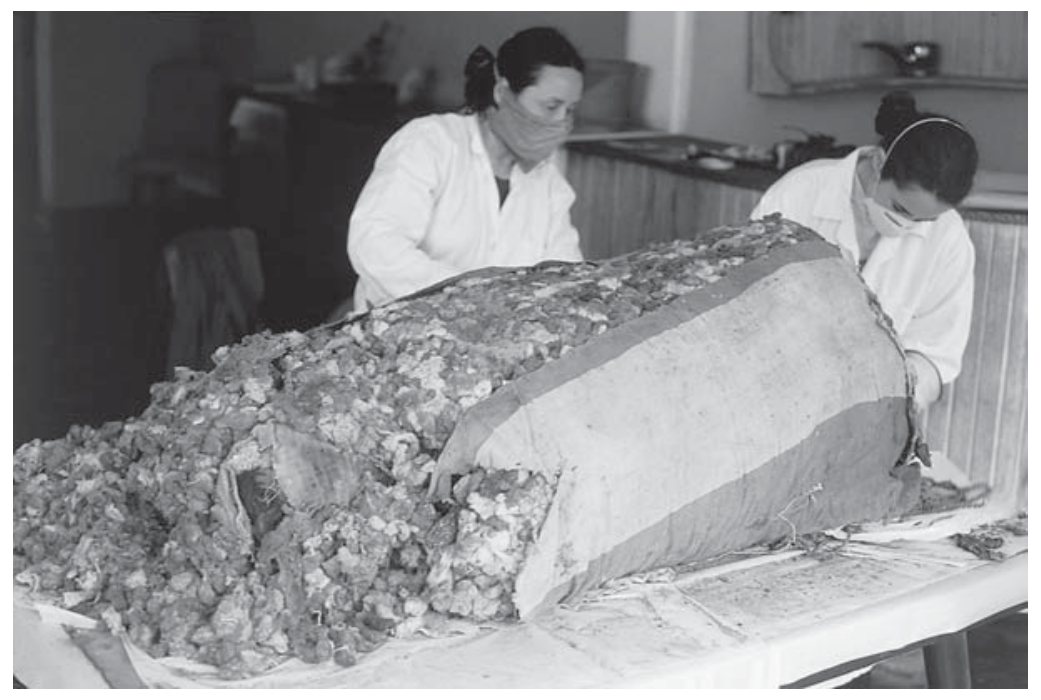

Fig. 1 - En las capas exteriores del fardo excavado en el Sector I en Rinconada Alta se notan una gruesa capa de algodón sin semillas y un vestido de mujer del estilo Inca. 
Entre ellos se encuentran prendas tejidas y distribuidas solo durante la corta época del dominio Inca, cuando aquellos serranos llegaron a la costa central del Perú (1470 - 1532 d.C.). Los efectos personales del difunto incluyen también prendas y accesorios que tienen características costeñas, lo que indica la continuidad y resistencia de las tradiciones que operaban por debajo del nivel de los intereses imperiales. Un examen minucioso de estas prendas, efectos personales y ofrendas, así como la construcción del fardo, enfocan nuestra visión de una forma más clara sobre la vida y tiempos de un hombre costeño, enterrado en Rinconada Alta.

\section{RINCONADA ALTA}

El sitio Rinconada Alta está ubicado en la margen sur de la parte baja del valle del Rimac, en el distrito limeño de La Molina (Fig. 2). El sitio, junto con otros sitios como Huaquerones-Puruchuco y La Puruchuca, está situado a lo largo del canal de Ate, el ramal más sureño del río Rimac. Anteriormente Rinconada Alta cubría aproximadamente veintidós hectáreas, y consistía en cementerios y una zona de viviendas. Hay evidencias de una larga ocupación del sitio, desde el Formativo Medio hasta el Horizonte Tardío (época Inca). Sin embargo, las ocupaciones más tempranas son bastante reducidas en comparación con la de la época Inca.

Cuando el proyecto actual comenzó en 1996(1), el sitio quedaba ya severamente destruido. Un noventa por ciento de la zona de viviendas y entre un setenta y un ochenta por ciento del cementerio habían desaparecido durante la construcción de un cementerio moderno, y lo que es más de lamentar, todo esto fue destruido por operaciones no autorizadas de extraccíon de arena. Lo que comenzó como un proyecto de rescate arqueológico antes de la expansión del cementerio moderno, se convirtió en un esfuerzo de investigación a largo plazo, en vista de que el estudio de los materiales arqueológicos excavados continúa hasta la actualidad. Muchos textiles eimplementos para producirlos fueron recuperados en entierros disturbados; y el estudio de los textiles realizado por los autores y otros investigadores (ver Agradecimientos) ha contribuido a la interpretación del fardo que aquí ofrecemos.

Una de las hipótesis propuestas es que la población que vivía en Rinconada Alta durante la época Inca correspondía a mitimaes, es decir, a unos colonos trasladados al sitio por los incas. Los colonos trasladados por los incas a nuevas regiones a veces se especializaban en la producción de bienes que eran recogidos y redistribuidos bajo el sistema tributario imperial (mit'a) (2). El descubrimiento de numerosas cesterillas textiles (costureros) y algunos cuantos equipos de herramientas para trabajar metales ponen de manifiesto la producción artesanal en este sitio. Los costureros de los

(1) Las tres temporadas de excavaciones llevadas a cabo en Rinconada Alta fueron conducidas por el arqueólogo de campo Daniel Guerrero, con autorización del Instituto Nacional de Cultura (RDN $\mathrm{N}^{\circ} 036$ firmado el 16/01/96). Seis sectores fueron excavados. El fardo fue recuperado en el Sector I en 1999, siendo registrado con el número de campo 1816-E3.

(2) La política incaica de reasentamientos sirvió para muchos propósitos: la introducción de cosechas o la producción local de ciertos bienes en nuevas zonas, el control de sectores insurgentes en el imperio, y la sustitución por nuevos colonos de poblaciones que estaban ocupadas en otro tipo de trabajo para el imperio (Betanzos, 1996[1551-1557]: 115, 120, 125, 170, 194, 202). 


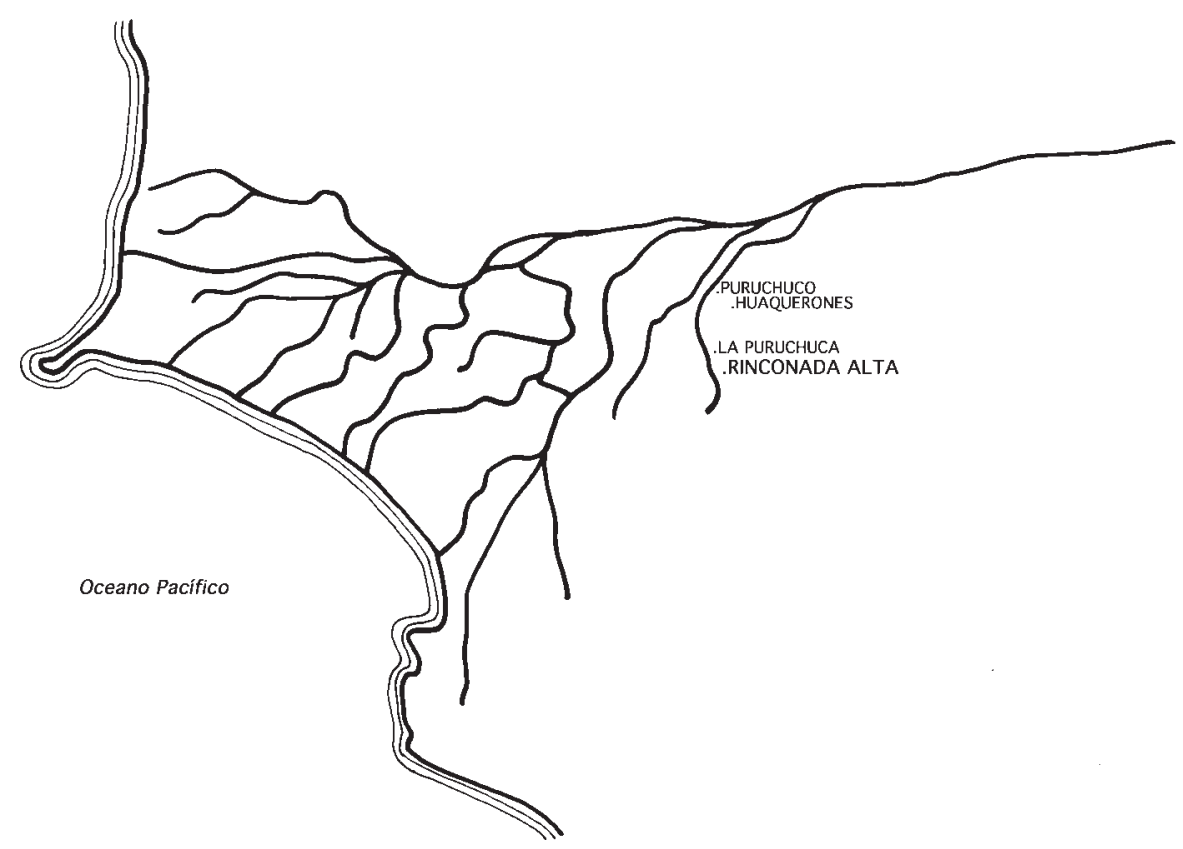

Fig. 2 - Mapa del valle bajo del Rímac que muestra Rinconada Alta y sitios cercanos.

tejedores, que contienen diversos útiles de textiles provienen generalmente de contextos disturbados (3). La cerámica, textiles y metales procedentes del sitio corresponden principalmente al estilo de la Costa Central, aunque no exclusivamente. Algunos objetos parecen ser de un estilo norteño (Chimú) y una pequeña cantidad podría provenir de la zona de Ica o de las serranías de Lima. Las evidencias inconfundibles de la influencia Inca se notan en los estilos y técnicas de los artefactos del sitio. Las indicaciones de actividades artesanales, la presencia de estilos foráneos, y las señales de influencia Inca en los textiles y la cerámica podrían indicar que la población de Rinconada Alta fue reasentada allí durante la época Inca (4).

Aunque resulta difícil interpretar el registro arqueológico tan complicado que refleja el control Inca en zonas costeñas, los estudios recientes sobre varios aspectos de los textiles Inca e Inca provincial han incrementado nuestros conocimientos sobre esta clase de objetos. Ahora es posible identificar prendas y proponer con mayor precisión las condiciones bajo las cuales varios tipos de prendas fueron confeccionados, utilizados y distribuidos. Las investigaciones recientes, así como los estudios publicados de fardos

(3) Un número de costureros con útiles e hilos fueron donados por algunos residentes que vivían en las cercanías del sitio.

(4) Esta hipótesis viene de la investigación y excavaciones llevadas a cabo por Daniel Guerrero Zevallos en Rinconada Alta y otros sitios de la Costa Central. El contenido del fardo funerario descrito aquí no contradice esta hipótesis, pero tampoco ofrece evidencias para apoyarla. 
comparables, serán aprovechadas aquí para explicar en cierta forma, el registro contenido en el fardo de Rinconada Alta.

\section{LA CAPA EXTERIOR DEL FARDO}

El fardo no era muy largo $(120 \mathrm{~cm})$ y tenía una circunferencia de $160 \mathrm{~cm}$. Fue encontrado en el Sector I por unos obreros que estaban sacando arena para el nuevo cementerio. El arqueólogo Daniel Guerrero Zevallos recuperó el envoltorio funerario del fondo de una fosa cilíndrica rellena de arena, cuyas dimensiones eran 2,5 m de profundo y 1,2 m de diámetro. No se encontraron ofrendas que acompañaban al fardo. El estado de conservación era más o menos regular, excepto por las fragmentadas soguillas exteriores y el deterioro parcial de la tela envolvente exterior.

Las soguillas que ataban el fardo (elemento 1) (5) estaban hechas de fibra vegetal, posiblemente juncus sp o typha sp. Las soguillas, fuertes y retorcidas, tienen un diámetro de $0,8 \mathrm{~cm}$ y están retorcidas en Z-2S, (o sea hiladas en $\mathrm{Z}$ y retorcidas en $\mathrm{S}$ ). Estos pequeños fragmentos no dan indicios sobre la forma original en que el fardo estaba atado (6). El envoltorio textil de algodón que rodeaba todo el fardo (elemento 2) es de color marrón medio en el centro, flanqueado por bandas anchas de color crema y bordes estrechos del mismo color que la sección central (Fig. 3). Este tejido de dos piezas está fabricado de una manera uniforme en ligamento llano con cara de urdimbre. Sin embargo dos secciones grandes en esquinas opuestas están deterioradas. En el momento en que fue armado el fardo, un fragmento arrancado de otro textil fue cosido a un extremo. Se supone que así lo hicieron para que el envoltorio textil fuese lo suficientemente largo como para cubrir todo el fardo. Hicieron que este primer textil o mortaja envolviese todo el fardo, mientras que el fragmento cosido fue extendido alrededor de los pies, al ser colocado el fardo en posición vertical. Unas puntadas gruesas aseguraron los bordes expuestos de la mortaja.

Esta mortaja exterior nos brinda una historia interesante. Las medidas, el listado y la densidad del ligamento del textil principal están conformes con las de un vestido estandarizado de estilo Inca fabricado en la costa. Las características de los vestidos Incas para mujer, tanto costeños como serranos, han sido cuidadosamente descritas (Katterman \& Riddell, 1994; A. Rowe, 1997). Una gran cantidad de vestidos de algodón para mujer han sido registrados en el sitio de Rodadero, cerca de Tambo Viejo en el valle de Acarí (Katterman \& Riddell 1994). Este sitio parece ser un almacén pues se encontraron estos vestidos cuidadosamente doblados en pilas de paños, los cuales aún no habían sido cosidos entre sí. El largo de un vestido de Rodadero, tal como sale del telar ( que es diferente de la largura tal como se lleva) varía entre 148 y $182 \mathrm{~cm}$, mientras

(5) El Anexo 1 enumera los elementos y ofrendas en el orden de retiro de las seis capas del fardo.

(6) Stothert \& Yarberry (1979) describen el atado de cuerdas de un fardo de Ancón, fechado al Horizonte Tardío según los autores. Las amarras de un envoltorio funerario del Horizonte Tardío de Puruchuco-Huaquerones pueden ser observadas a través de fotografías (Cock, 2002: 81, 82). La dirección de la torsión de las soguillas de estos dos fardos es contraria a la de los fragmentos de soguilla encontrados en el exterior del fardo que se comenta aquí. 


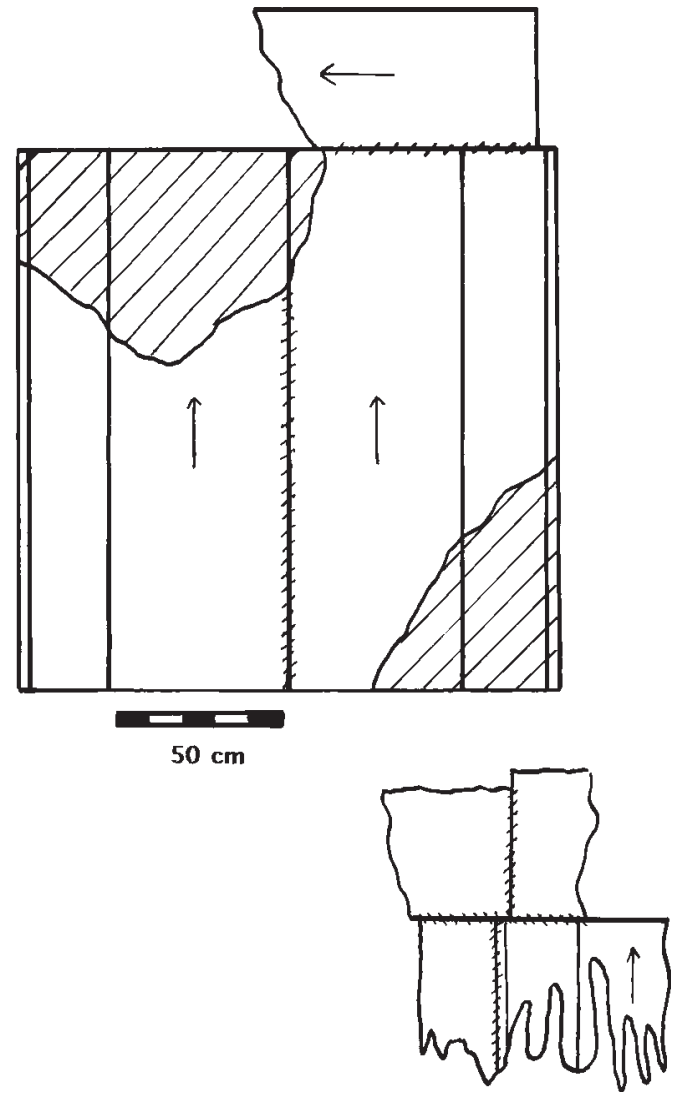

Fig. 3 - Dibujo del vestido Inca y el fragmento añadido (elemento 2) que cubría el exterior del fardo $(209 \times 164 \mathrm{~cm})$. Un fragmento de otro vestido femenino encontrado en la última capa del fardo fue cosido con tres paños fragmentados (elemento 18).

que el ancho, a base de dos piezas del telar, oscila entre 136 y $176 \mathrm{~cm}$. El largo y el ancho del vestido convertido en mortaja del fardo de Rinconada Alta miden $166 \mathrm{~cm}$ y $164 \mathrm{~cm}$. El tamaño y la disposición de las bandas laterales de color coinciden con los de los vestidos de Rodadero. También coincide la textura espesa de la tela.

El almacenamiento de vestidos y mantos de mujer en el sitio de Rodadero indica que todos fueron tejidos en cantidades considerables en el Valle de Acarí. A lo mejor fueron confeccionados para el cumplir el trabajo de tributo (mit'a) impuesto a la población por los incas (Katterman \& Riddell, 1994:148; A. Rowe, 1997:14, 34). Los tejedores podrían haber sido vecinos de la región, o tal vez colonos (mitimaes) dedicados a la producción de ropa para el régimen imperial (y liberados de otros tipos de obligaciones de mit'a). Tal vez los especialistas cosían y remataban las piezas. Después de esto los vestidos estaban listos para ser distribuidos por los incas. Fragmentos de vestidos semejantes han sido documentados entre los restos de entierros disturbados de Rinconada Alta. 
Son tan uniformes los vestidos Inca de algodón provenientes de muchas zonas diferentes de la costa que es difícil saber si fueron fabricados en su vecindad o si fueron recibidos por los vecinos bajo la política imperial de dádivas, conocida como la reciprocidad. Es probable que los vestidos Inca de algodón fueran confeccionados y recogidos en diversas partes de la costa en el cumplimiento de la mit'a. Hasta la actualidad, no hay forma de determinar dónde fue tejido el vestido del fardo de Rinconada Alta.

Los vestidos de este tipo, cuando no se llevaban puestos, son paños cuadrados con bandas simétricas de color, estando compuestos de dos piezas del telar hechas en ligamento llano con cara de urdimbre. Dichos vestidos habrán sido llevados de manera que envuelven el cuerpo con las bandas de color colocadas horizontales, y ceñidos con una faja. Las puntas están sujetadas con alfileres en los hombros. Este vestido de tipo envolvente es más de origen serrano que costeño (7). A pesar de que el estilo es serrano, el uso del algodón indica que probablemente fueron confeccionados en la costa, de acuerdo con un tamaño estandarizado establecido por los incas. Ahora están disponibles las medidas y los detalles técnicos y de diseño para una gran cantidad de prendas estandarizadas, tanto de hombre como de mujer (túnicas, mantos, vestidos y chales) de modo que se pueden efectuar comparaciones (Julien, 1999; Katterman \& Riddell 1994; Katterman, 2002, 2005; A. Rowe, 1997; Uhle, 1991[1903]).

Es evidente que el envoltorio exterior del fardo es un vestido de mujer, mientras que el individuo enterrado es hombre, lo que parece una anomalía. Podemos comprender mejor esta situación si recordamos la condición fragmentaria del vestido y la pieza añadida (Fig. 3). Es posible que esas telas pudieran ser extraídas de otras tumbas para obtener una tela envolvente lo bastante larga como para rodear todo el fardo, una circunstancia que podría explicar su condición fragmentaria, así como la anomalía del sexo. Otra explicación posible es que el vestido ya no sirvió para tal y cayó en desuso (por desgaste, roturas, etc.) pero que fue guardado y adaptado después para envoltorio de fardo. Otros cuatro fragmentos rotos fueron utilizados como relleno alrededor de las piernas en el fardo (elemento 18). Uno de estos es fragmento de otro vestido, cuya identificación ha sido hecha en base al tamaño y disposición de la banda de color y la densidad del ligamento. La reutilización de textiles desgastados o que provienen de otros entierros podría haber sido una práctica bastante común, ya que se encuentran fragmentos en otros fardos. Exceptuándose los determinados fragmentos mencionados aquí, los textiles estaban enteros cuando fueron colocados en este fardo, y corresponden a prendas llevadas o utilizadas por hombres.

Entonces la capa exterior del envoltorio funerario de La Rinconada Alta nos ha proporcionado algunas sorpresas, a pesar de no estar totalmente intacta: el uso de un vestido de mujer para envolver el fardo de un hombre y la reutilización probable de

(7) Los vestidos costeños de las épocas tardías tienen una forma y construcción totalmente diferentes (Uhle, 1991[1903]: 68, Fig. 94; Prümers, 1998; Aponte, 2000). Son vestidos holgados compuestos de varias piezas de tamaños diferentes, y presentan típicamente pliegues verticales en la delantera y aberturas horizontales para los brazos y la cabeza en la costura de los hombros. Una cantidad de fragmentos de vestidos costeños están presentes entre los textiles recuperados de tumbas disturbadas en el sitio Rinconada Alta. 
textiles sacados de otras sepulturas. Lo que menos nos sorprende, debido a la presencia de otros artefactos Inca en el fardo, es la indicación clara de que el envoltorio estaba rodeado por un textil que fue confeccionado según las dimensiones y proporciones estandarizadas de los incas.

\section{CAPA 2 DEL FARDO}

Debajo del vestido/mortaja había una gruesa capa de algodón (Gossypium barbadense) de varios colores al que se le habían extraído las semillas (elemento 3). Dentro del algodón se encontraron pequeñas ofrendas de sustancias animales, vegetales y minerales. Un material orgánico masticado, posiblemente granos de maíz, fue hallado cerca de la cabeza (ofrenda 1) y de los pies (ofrenda 7) del entierro. Una pluma verde brillante, posiblemente de papagayo (ofrenda 2), una costilla humana que medía $10,5 \mathrm{~cm}$ (ofrenda 3), semillas de calabaza (ofrenda 4), una hoja de coca (ofrenda 5) y una lasca de piedra negra (ofrenda 6) fueron recuperadas dentro de la enorme cantidad de algodón. Otros pequeños objetos identificados como siendo de la segunda capa, los cuales podrían haber sido incluidos sin querer en el algodón circundante fueron fragmentos de cáscaras de maní, varias hojas sin identificar, un fragmento de caña y un tallo de de frijol. Otras ofrendas principales de esta capa incluyen una valva de spondylus con los bordes color naranja, la cual estaba colocada al pie del fardo (ofrenda 9), y una calabaza (¿lagenaria siceraria?) con forma de foco (ofrenda 10). La calabaza no presenta decoración alguna y tiene un tapón de algodón, habiendo sido colocada en la zona donde se encontraba el pecho del difunto, debajo del nivel de las fibras de algodón. El contenido de la botella no ha sido analizado, pero podría ser cal, una sustancia alcalina que se colocaba en la boca junto con la coca para soltar el estimulante de las hojas. Una segunda calabaza que tenía un tapón tallado en madera (ofrenda 16c), fue encontrada dentro del contenido de una bolsa tejida que había sido metida muy en el interior del fardo.

La capa espesa de relleno de algodón cerca del exterior del fardo es una señal precisa que indica que el entierro fue realizado durante la época del dominio Inca del valle costeño del Rímac. Daniel Guerrero Zevallos ha desarrollado una tipología de los fardos funerarios procedentes de los sitios ubicados en las cuencas del Rímac y Lurín. Una capa de relleno de algodón es una característica constante de los entierros de la época Inca. Otro fardo que tenía una capa de algodón crudo fue excavado en el sitio cercano de Puruchuco-Huaquerones por Guillermo Cock (2002). Este también es de la época Inca, según lo confirma la presencia de una bolsa tejida al estilo Inca y otros objetos del fardo.

\section{CAPA 3 DEL FARDO}

Al retirarse la capa de fibras de algodón, cuyo espesor era variable, se hizo manifiesto el contorno general del cuerpo (Fig. 4). Las rodillas del individuo estaban fuertemente flexionadas, pero las caderas no lo estaban.. El ángulo obtuso formado por el torso recto y los muslos indicaba que el cuerpo había sido colocado en una posición atípica. Él no tenía las rodillas apretadas hacia el pecho, según la posición observada 


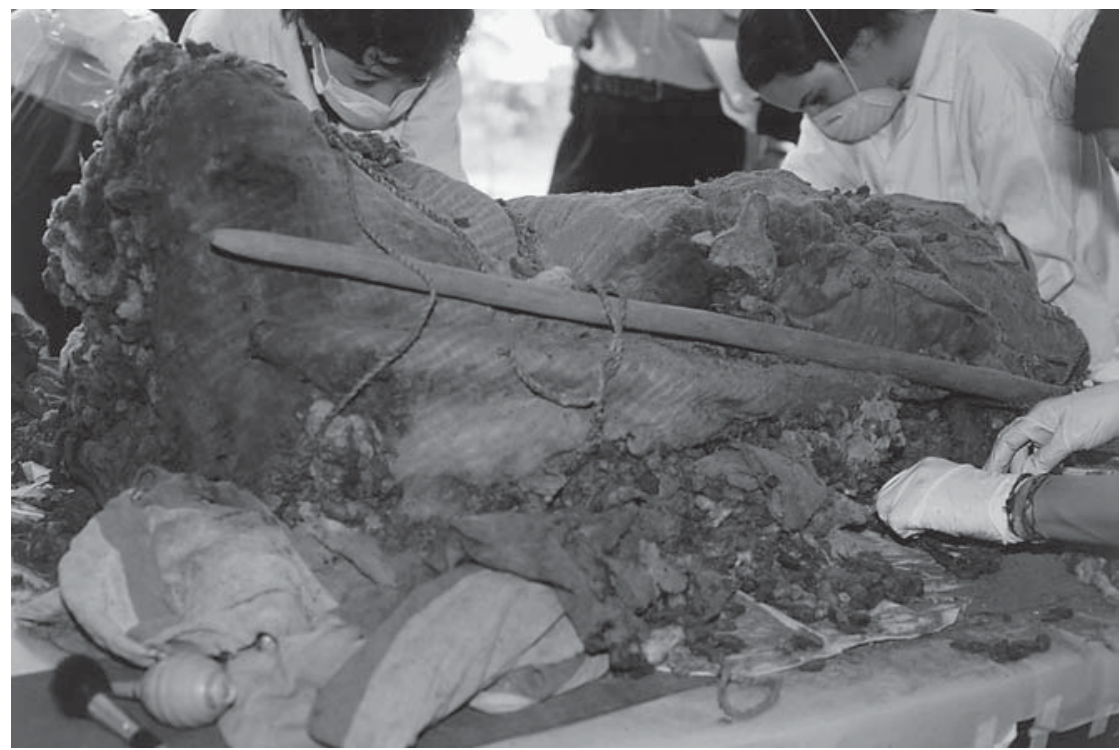

Fig. 4 - Después de retirar la capa de algodón, se hace más visible en la capa 3, la postura arrodillada del difunto, con las rodillas dobladas y el torso derecho.

comúnmente en los entierros de la Costa Central (Schmidt, 1929: 556-558; Reiss \& Stübel, 1880-1887: Láminas 20, 30). Cuando el fardo fue puesto parado, el cuerpo mostraba una posición arrodillada/sentada, con las pantorrillas colocadas debajo de sí. Al parecer, algunos palos de madera hallados en esta capa y en otra al interior le mantenían erecto el torso.

La tercera capa del fardo consistía en un textil envoltorio grande, dos palos de madera, fragmentos de cuerdas que ataban los palos de madera al fardo, y una ofrenda de cuatro mazorcas de maíz rojo (Zea mays). Las cuerdas (elemento 4), retorcidas de fibra vegetal, estaban hiladas en $\mathrm{S}$ y retorcidas en $\mathrm{Z}$. Tienen un tono más rojizo y son más finas que aquellas utilizadas al exterior del fardo, y también están hiladas y retorcidas en una dirección opuesta. Las ataduras de cuerda estaban rotas, pero mantenían más o menos su posición original. Una cuerda cruzaba la base del fardo, luego se entrecruzaba con una sección de la misma cuerda que pasaba por encima de los muslos del difunto. Otro par de cuerdas pasaba por encima de la zona del vientre, y otro más circundaba la zona del pecho. Las cuerdas rodeaban tanto al cuerpo como los largos palos de madera dispuestos al lado del cuerpo, fijando los palos en su sitio. Ambos palos son gruesos y bien acabados, fabricados de una madera pesada. El palo de madera ubicado en el lado izquierdo del cuerpo (elemento 5), presenta un extremo más ahusado, con un largo de $121 \mathrm{~cm}$ y una circunferencia de $9,5 \mathrm{~cm}$. El palo de madera del lado derecho (elemento 6) es menos ahusado y un poco más pequeño, con un largo de $105 \mathrm{~cm}$ y una circunferencia de $8,5 \mathrm{~cm}$. A lo mejor los palos servían para otros propósitos antes de ser incorporados en el fardo para darle rigidez a la postura del difunto. 
Cuatro mazorcas de maíz (ofrenda 10) fueron colocadas cerca de la barbilla, en el lado derecho del cuerpo. Las mazorcas son rojas y miden entre 7 y $12 \mathrm{~cm}$ de largo. Debajo del maíz, los palos y las cuerdas había un solo textil envolvente (elemento 7), que rodeaba totalmente el cuerpo del individuo. Después de deshacer las gruesas puntadas que sujetaban los bordes de la tela, los rasgos del envoltorio pudieron ser descritos.

El tejido está compuesto de tres piezas de telar largas $(147 \mathrm{~cm})$ y cosidas juntas a lo largo de los orillos laterales (Fig. 5a). El fardo fue echado diagonalmente sobre este tejido grande y las dos esquinas laterales y opuestas fueron dobladas por encima de él. Despúes, las dos esquinas del pie y de la cabeza del fardo fueron dobladas hacia adentro también. Finalmente, todo borde expuesto del textil envoltorio fue cosido con puntadas grandes y anudadas.

La textura y la forma del tejido envolvente son muy diferentes del vestido Inca del exterior del fardo (elemento 2), lo que supone una tradición textil distinta. El textil envolvente es una tela más flexible, siendo fabricado de tres piezas de telar cuyo ancho es menos que el del vestido Inca. Las características físicas de la tela coinciden con la tradición costeña de tejer textiles de algodón en un telar de cintura que se puede tensionar con el movimiento del cuerpo. En la tradición costeña, las urdimbres, que son los hilos dispuestos verticalmente en el telar, son más finas y están un poco más espaciadas que las urdimbres del vestido Inca del exterior del fardo. Los hilos que atraviesan las
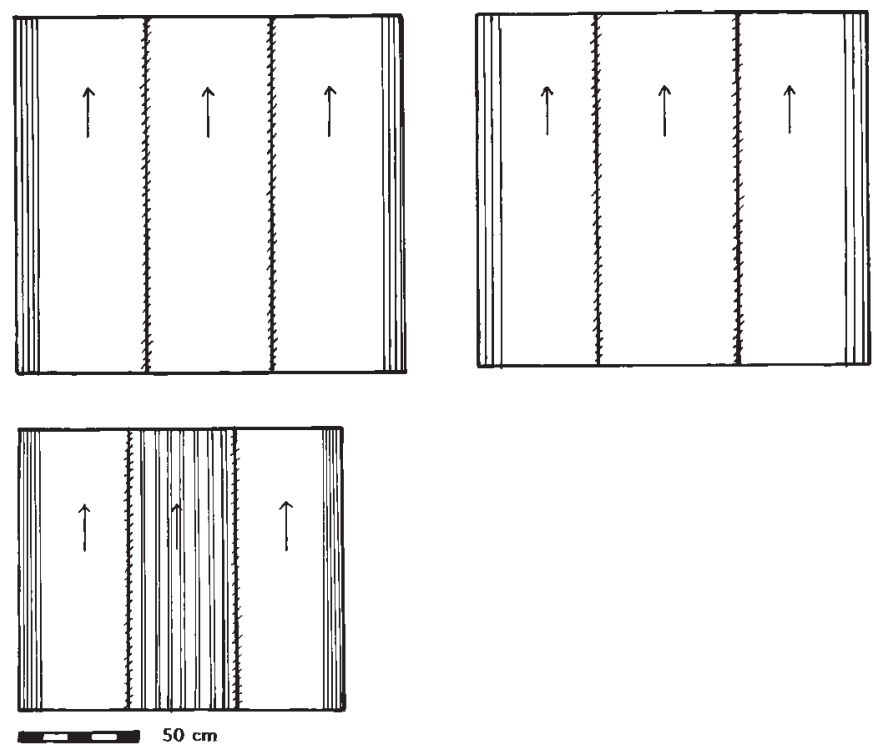

Fig. 5 - Dibujos de los mantos a cuadros y listados usados como mortaja en las capas 3, 4, y 5 del fardo. Las flechas indican la dirección de la urdimbre. a) Elemento 7: 147 x $160 \mathrm{~cm}$; b) Elemento 8: $145 \times 162 \mathrm{~cm}$; c) Elemento 9: 116 x $134 \mathrm{~cm}$. 
urdimbres, denominadas tramas, pueden ser vistas parcialmente entre las primeras. Este tipo de ligamento llano se llama de "urdimbres predominantes", mientras que el tipo de ligamento llano del vestido Inca del exterior del fardo se llama de "cara de urdimbre" (Emery, 1966; A. Rowe, 1977). La alternación de los colores en los hilos de la trama y de la urdimbre del textil envolvente resulta en un tejido con una apariencia de cuadros sútiles. Las listas de color azul y marrón oscuro que se encuentran a lo largo de los orillos laterales contrastan con los hilos de color beige y canela de la tela a cuadros. Estas listas muestran un diseño sencillo de ajedrez tejido por medio de hilos flotantes.

Tejidos semejantes han sido encontrados en muchos sitios de la Costa Central durante los periodos tardíos, tanto antes como durante la época Inca. Muchos tejidos a cuadros y listados aparecen en contextos funerarios (Reiss \& Stübel, 1880-1887; Cock, 2002: 85-86), pero a lo mejor servían para otra cosa antes de ser utilizados como textiles envoltorios. El hombre de Rinconada Alta poseía tres tejidos enteros de este tipo (elementos 7, 8, y 9; Figs. 5a, b, y c). Los textiles de tres piezas del telar serán mantos masculinos de estilo costeño, una hipótesis que se ve reforzada por el hecho de que no se encontraron mantos de estilo Inca en el fardo (8).

\section{CAPA 4 DEL FARDO}

La cuarta capa del fardo dio a luz ofrendas arregladas como paquetes dentro de paquetes, así como otra textil envolvente de tres piezas y un tocado de plumas con muchos adornos. Dos pequeños rollos de fibras vegetales no torcidas, posiblemente de furcraea, fueron colocados uno cerca de la cabeza (ofrenda 11) y otro a los pies (ofrenda 12). Ambos fueron enrollados con mucho cuidado en paquetes con un largo de $3,3 \mathrm{~cm}$ y $4,5 \mathrm{~cm}$. Fueron asegurados por unas de las mismas fibras enrolladas alrededor de ellos.

Un tocado de plumas (ofrenda 14) fue encontrado debajo del hombro y al lado izquierdo del cuerpo, entre el textil envolvente de la capa 3 (elemento 7) y el textil envolvente de la capa 4 (elemento 8). A pesar de que la tela base y las plumas están deterioradas en cierto grado, el tocado está básicamente entero. Consiste en un gorro de tela rematado con un penacho de plumas (Fig. 6). El penacho consiste en algunas plumas grandes a las que han agregado unas plumitas por medio de un cordón fino que envuelve las púas de cada grupo de plumas. Un paño colgante está sujeto a la parte trasera del gorro. Tanto el gorro como el paño colgante están adornados con sartas de pequeñas plumas cosidas a la tela base. Las plumas del tocado son mayormente marrones y blancas, pero se notan plumas verdes incorporadas en un diseño del paño posterior. Estas plumas verdes ahora se encuentran oscurecidas por la carbonización.

Tocados semejantes, algunos más impresionantes, han sido recuperados de Rinconada Alta y sitios aledaños (Cock, 2002: 91), asícomo de la Costa Norte (A. Rowe, 1984: figures 191, 194-197). Rowe considera que los tocados de pluma son una

(8) Otros fardos de la Costa Central repiten la pauta de incluir mantos de estilo costeño y túnicas Inca o de influencia Inca. Uhle (1991: 37-39) menciona túnicas y mantos de diferentes estilos en dos tumbas (A y B) de Pachacamac, e ilustra túnicas Inca y de influencia Inca. A. Rowe (1997: 33), quien hizo una revisión de muchos textiles de Pachacamac que ahora están almacenados en el Museo de la Universidad de Filadelfia, notó que los mantos de las tumbas A y B no son Inca. 


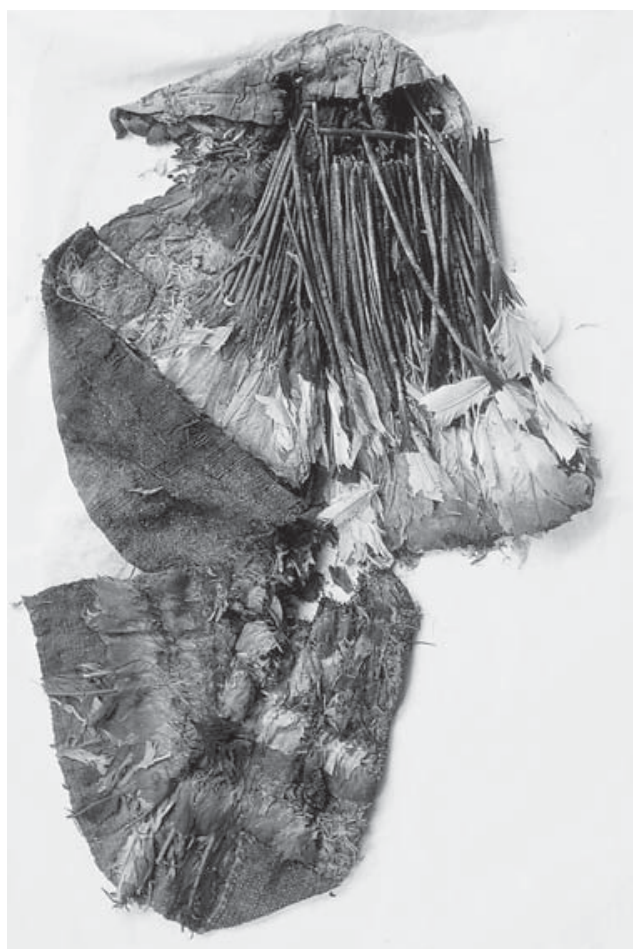

Fig. 6 - Un tocado de plumas con gorra, paño trasero y penacho (ofrenda 14) estaba colocado debajo del hombro izquierdo, entre las mortajas de las capas 3 y 4 .

especialidad de los Chimú, basándose en los rasgos técnicos de la tela base (1984:175184) y otras evidencias. Los tocados estudiados por ella coinciden en el uso de urdimbres pareadas hiladas en $\mathrm{S}$ en el ligamento llano de la tela base. Este rasgo predomina en los textiles Chimú. El paño colgante del tocado de Rinconada Alta muestra la estructura identificada por Rowe como Chimú, o sea un ligamento llano con las urdimbres pareadas e hiladas en $\mathrm{S}$, pero no es así en el caso del gorro. Es posible que los tocados de plumas de este tipo hayan seguido siendo confeccionados por los especialistas Chimú para abastecer los almacenes Inca.

Los tocados muy ornamentados muestran un par de paños estrechos sujetos a cada lado del gorro, además del paño posterior colgante; algunos están decorados con plumas de los colores brillantes de las aves selváticas. Si bien estos tocados son lo bastante raros como para considerarlos prendas prestigiosas, también hay un número suficiente como para distinguir varios niveles de prestigio entre la muestra de veinte ejemplos publicados y sin publicar. El hombre de Rinconada Alta fue sepultado con un modelo más sencillo y menos pintoresco (9).

(9) A. Rowe (1984: 177-78) ha sugerido que los tocados de plumas marrones y blancas podían ser de la época colonial, basándose en la hipótesis que las rutas de intercambio utilizadas para obtener plumas de colores de la selva habrán sido interrumpidas durante la conquista española. Es igualmente 
Betanzos (1996[1551-1557]: 105) cuenta que, según las leyes ordenadas por el Inca Yupanqui, nadie podía vestir ropa fina ni plumas, a no ser que las vestimentas hubieran sido otorgadas por el soberano mismo a cambio de servicios recibidos. Si Betanzos describió con acierto el control mantenido por los Incas sobre las prendas de plumas, el tocado indica que el hombre de Rinconada Alta había alcanzado cierto grado de favor con los incas.

Aunque se supone que los tocados de plumas eran llevados por personas de cierta distinción sociopolítica, las representaciones artísticas y en las crónicas sugieren que los soldados también los usaban. Una figurina de plata del Museo Americano de Historia Natural (B/9588; A. Rowe, 1984: figura 192), posiblemente de la época colonial, muestra a un hombre que lleva una porra estrellada y usa un tocado y un tabardo de plumas. Los tocados de plumas también están representados en los dibujos que hace Guaman Poma de capitanes nobles y un soldado plebeyo. Largos paños posteriores y/o paños laterales se extienden del casco de guerra hacia abajo (2002[1615]: 147, 149, 151, 153, 161, y 196). En las escenas de guerra de la crónica de Guaman Poma, es el líder de la unidad de combate Inca quien usa los paños distintivos que están colgados del casco.

El gorro y los paños emplumados del tocado, usados con un casco, podrían haber protegido el cuello durante los encuentros militares mejor que el penacho de plumas erguidas en la parte superior del casco. Los paños colgantes, dispuestos en capas y cubiertos de plumas, estaban acolchados con puntadas que sujetaban las sartas de plumas y podían haber servido de una armadura de poco peso. Los tabardos emplumados, que se conservan también en cantidades considerables podrían haber protegido la parte superior del cuerpo de los guerreros que luchaban de cerca. Pachacuti Yanqui cuenta que Yáhuar Huácac hacía sus preparativos para la guerra ordenando que se dispusiera ropa emplumada junto con otras prendas con placas de metal para proteger el pecho y los hombros de los militares contra las flechas y lanzas (1995: 55). Murra cita a bastantes cronistas para demostrar que la ropa decorada con plumas tenía una asociación especial con los militares y la guerra (1980: 77).

La presencia del tocado emplumado en el fardo del hombre de Rinconada Alta indica que uno de los papeles que desempeñaba en la vida fue el de ser soldado, ya que el servicio militar era uno de los deberes con que los tributarios tenían que cumplir por turnos para el imperio. Si nuestro soldado fue o se convirtió en líder de una unidad regional dentro del ejército imperial, podría haber recibido el tocado de plumas por su valor o liderazgo. El Inca disponía de un sistema detallado de honores y recompensas para militares, y a los individuos la valentía en la guerra les permitía atravesar una barrera social, "la que de otra forma era hereditaria e impenetrable" (Conrad \& Demarest, 1984: 124). El tocado de plumas es una entre varias señales del fardo que demuestra que el hombre de Rinconada Alta podría haber alcanzado un buen nivel de liderazgo en la burocracia provincial Inca, posiblemente a través de servicios distinguidos como soldado.

posible que los tocados marrones y blancos hayan representado el extremo inferior de una escala Inca de prestigio, donde los tocados que exhiben plumas de color y figuras estaban en el extremo superior de la escala. Las túnicas hechas de algodón o de fibra de camélido en tonos naturales (crema, canela y marrón) también parecen ser de menor prestigio que las túnicas en tapiz que están teñidas y muestran diseños. 
El vínculo establecido por Conrad y Demarest entre la valentía en la guerra y el ascenso social de los provincianos dentro de la burocracia estatal podría indicar que un regalo prestigioso, tal como un tocado de plumas, era usado en situaciones tanto ceremoniales como militares. En las situaciones ceremoniales nuestro soldado podría haber usado el tocado con penacho mientras que en la batalla lo llevaba sin penacho, para servir de armadura.

Una ofrenda compleja dentro de la cuarta capa del fardo apoya la hipotesis que el difunto de Rinconada Alta era un hombre destacado en asuntos civicos y militares y que esa distinción era modesta pero significante. Un paquete envuelto en telas, que contenía ropa poco corriente y otros objetos, fue colocado al lado ventral del cuerpo (Fig. 7), extendiéndose desde la barbilla hasta la mitad del muslo (ofrenda 13). El paquete contenía dos túnicas decoradas (ofrendas 13b y 13c), un taparrabo (13d) y un bulto anudado (13e) que estaba relleno de hilos, fibras no hiladas y varias pequeñas bolsas rellenas de hojas (Fig. 8). Ambas túnicas muestran una influencia Inca, pero una parece estar relacionada con un papel sociopolítico, mientras la otra puede estar relacionada con un papel militar (10).

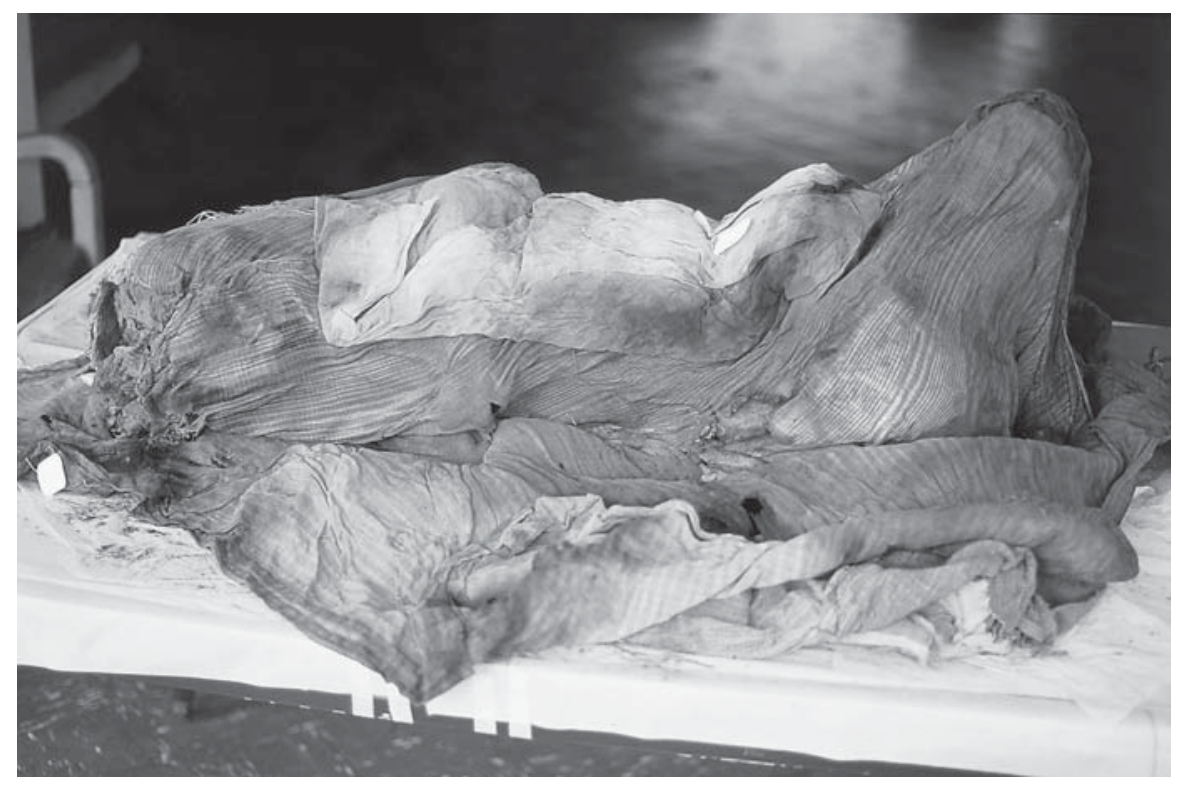

Fig. 7 - El paquete cuidadosamente doblado (ofrenda 13), que se encontró en el centro sobre el torso en la capa 4 , contenía telas, hojas, hilos, fibras vegetales y gránulos de concha quemada.

(10) Las dos túnicas sin mangas fueron dobladas de una manera al parecer proscrita: dos dobleces verticales seguidos por dos horizontales. Al ser desdoblada la túnica, las arrugas formaban dieciséis cuadrados iguales. Esta forma de doblar una túnica ha sido observada en una túnica de tapiz Inca con una banda en la cintura que muestra un diseño de rombos (A. Rowe, 1978: fig. 4). 


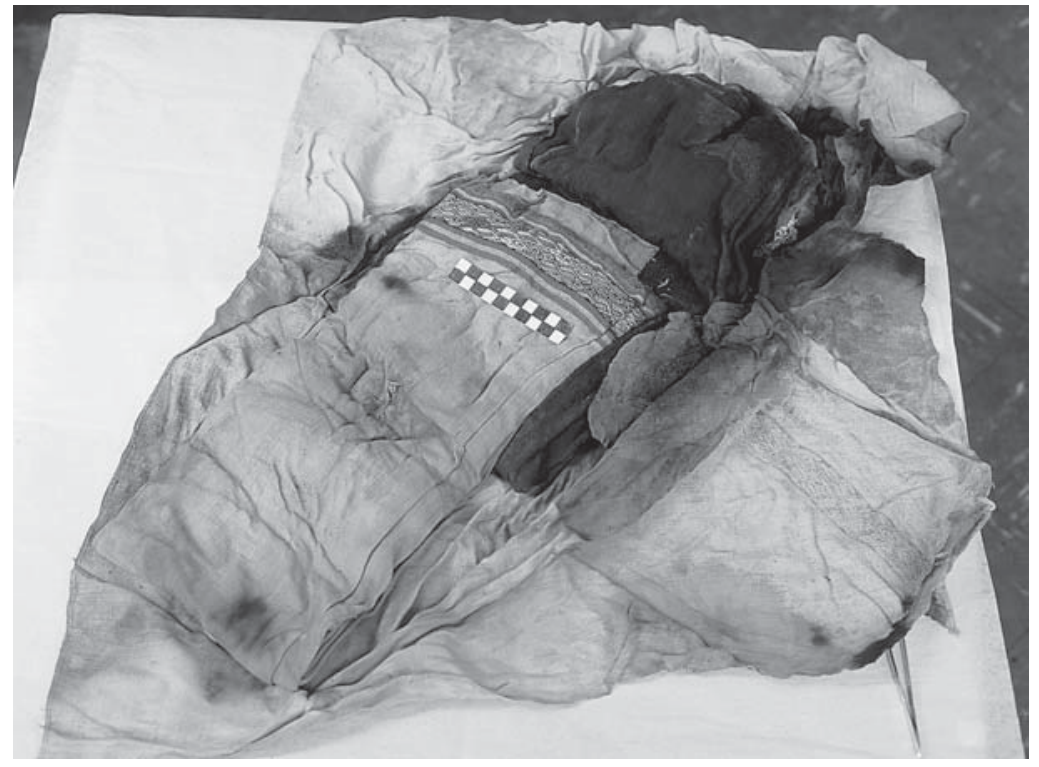

Fig. 8 - Cuando las esquinas del paquete (ofrenda 13) fueron desdobladas, dos túnicas dobladas (ofrendas 13b y c) fueron expuestas.

La primera túnica (ofrenda 13b) tenía las proporciones largas y estrechas de una túnica Inca, pero los rasgos exhibidos en su confección, la textura de la tela y el diseño del borde coinciden con la tradición costeña (Fig. 9). La túnica tiene 93,5 cm de largo y $73 \mathrm{~cm}$ de ancho, medidas dentro de las normas para las túnicas de tapiz Inca (Julien, 1999: Cuadro1). Las túnicas del estilo Inca imperial suelen ser confeccionadas de una sola pieza del telar. Esta túnica está tejida en dos piezas del telar, cosidas entre sí con una costura central, un rasgo constructivo y típico de las túnicas cortas y anchas usadas en la costa. También se notan un diseño y técnicas costeñas en el borde de aves entrelazadas, tejidas con hilos de camélido de colores vivos. Los fragmentos de túnicas costeñas cortas y anchas excavados en Rinconada Alta, Armatambo y Pachacamac (Uhle, 1991[1903]: figura 50) presentan unos bordes semejantes. La textura de la tela, que es de un ligamento llano, y el ligamento del diseño del borde que es un ligamento de tramas complementarias, son conformes con los textiles tejidos en un telar de cintura, que se tensiona por el movimiento del cuerpo. Este tipo de telar fue utilizado en muchas zonas costeñas..

La túnica es una mezcla de rasgos costeños e Inca pues une el tamaño y proporción de las túnicas Incas con las características constructivas y decorativas de las túnicas costeñas. A. Rowe (1992), quien ha publicado ejemplos de túnicas híbridas Inca que provienen de muchas regiones de la Costa Sur y Norte, los denomina estilos “Inca provincial”. Esta túnica parece ser de un estilo Inca provincial usado en la Costa Central (11).

(11) Hay una variedad considerable de túnicas Inca provincial, provenientes de sitios de la Costa Central. La sección superior de las túnicas puede ser decorada en un ligamento de gasa, un ligamento flotante, un ligamento de tapiz o de brocado, y puede mostrar una gran variedad de diseños geométricos o figurativos. 


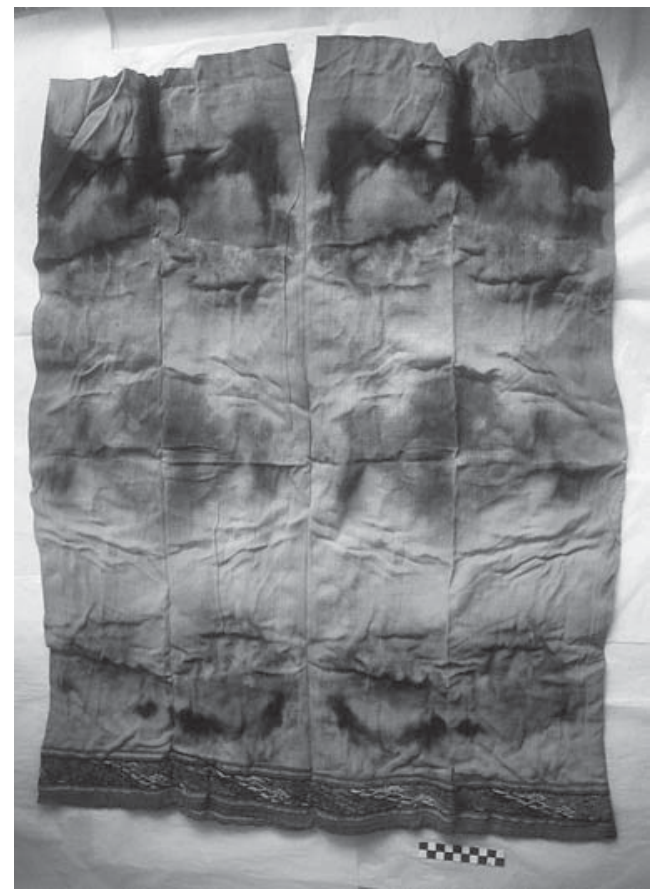

Fig. 9 - La túnica Inca provincial (ofrenda 13b) combina técnicas, materiales y diseños costeños con las proporciones de una túnica Inca $(93,5 \times 73 \mathrm{~cm})$.

La existencia de túnicas de muchos estilos Inca provincial indica que la mezcla de características era una manera de vincular las comunidades regionales con el Imperio Inca. Una túnica Inca provincial afirma la afiliación regional del que la usa (a través de la decoración y técnica), pero también reconoce que el estatus local está encerrado dentro de una estructura política imperial (a través del tamaño y medidas estandarizadas). Es de suponer que los funcionarios provinciales del imperio, tenían el derecho y la razón por usar una prenda de forma Inca con diseños costeños. El fuerte control impuesto por el Inca sobre los códigos de la indumentaria indica que el derecho de usar una prenda de estilo Inca provincial tenía que ser ganado. Como el valor militar era la forma principal de movilidad social para los plebeyos en las provincias (Conrad \& Demarest, 1984: 123), es razonable pensar que el hombre de Rinconada Alta puede haber entrado por el peldaño más bajo de la burocracia provincial a través del servicio militar.

La ropa era un medio efectivo para exteriorizar las alianzas entre el imperio y las provincias, y los incas lo explotaban de otras formas. Betanzos cuenta que el Inca Huayna Capac, cuando visitaba las provincias, paraba en las afueras de los pueblos y se vestía la ropa y el tocado de los vecinos (1996[1551-1557]:168-9). En la situación descrita por Betanzos, parece probable que el Inca, o su enviado desde la capital, pudiera haber vestido una túnica Inca provincial, en vez de una prenda muy de estilo local. El uso de una túnica Inca provincial podría haber sido una demostración gráfica de alianza, la cual seguramente iba a halagar y complacer a la población de la vecindad.. 
La indumentaria de estilo Inca provincial podría haber servido para controlar a las poblaciones provinciales, a quienes no les estaba permitido movilizarse libremente fuera de sus propias provincias. Según Cobo, era fácil reconocer a la gente de diferentes naciones o provincias que asistía a cualquier asamblea del Inca, o iba a la batalla, por medio de la indumentaria y el tocado (1983[1653]: 196-197]).

La segunda túnica del fardo (ofrenda 13c), corresponde a una de las clases de túnicas Inca con “diseños estandarizados” descritas por J. Rowe en su artículo original (1979: fig. 15). La túnica presenta un diseño de cuatro cuadrados concéntricos en la mitad inferior (Fig. 10). Los contornos concéntricos del diseño alternan entre negro y blanco, y un cuadrado mayor de color blanco encierra los cuatro cuadrados. El diseño de la túnica, denominada casana, es uno de los pocos diseños para el cual tenemos registrado un nombre en la lengua indígena. Guaman Poma menciona el nombre casana (caxane) al describir la túnica llevada por el Inca Maita Capac en su crónica ilustrada (2002 [1615]: 98). El diseño casana de la túnica de Maita Capac, como el del hombre de Rinconada Alta puede ser producido en dos colores: los cuadrados concéntricos parecen flotar el uno dentro del otro y juntos se destacan sobre el cuadrado de fondo. El Inca Maita Capac, quien lleva un casco de guerra y carga armas, está representado en su papel de guerrero.

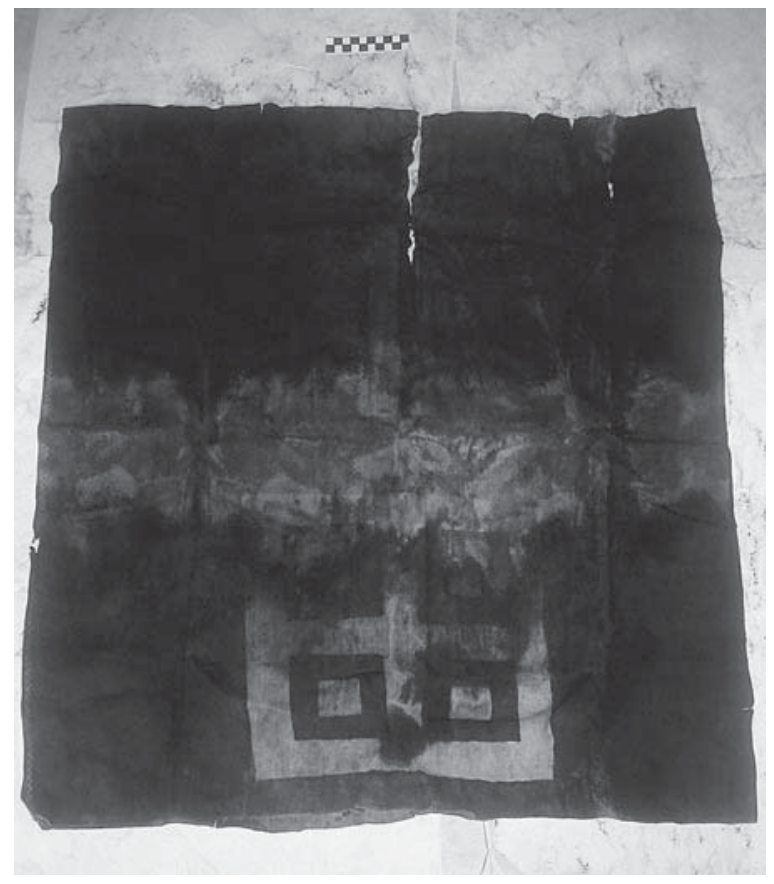

Fig. 10 - La túnica en teñido de reserva (ofrenda 13c) exhibe el diseño estandarizado de la casana. Los tintes se han corrido debido a la humedad dentro del fardo, lo cual ha oscurecido un poco el diseño de cuatro cuadrados concéntricos $(83,5 \times 79,1 \mathrm{~cm})$. 
La túnica casana de Rinconada Alta se parece a una túnica entera, tejida en ligamento de tapiz con hilos de camélido, la cual lleva también un diseño casana en negro y blanco (National Museum of Natural History, Smithsonian 307 655, J. Rowe, 1979: figura 15; Zuidema, 1991: figura 9b). Una túnica de algodón en ligamento de tapiz (Peabody Museum of Archaeology and Anthropology, Harvard 46.77.30/7684) muestra también un diseño casana bicolor (marrón y rosado), pero no está entera. Ambas túnicas en tapiz están tejidas de la manera serrana, en una sola pieza del telar utilizando la técnica del tapiz trabado. La túnica de algodón del fardo tiene más o menos las proporciones y dimensiones de la túnica entera de camélido $(83,5 \mathrm{~cm}$ x 79,8 cm) y $(88 \mathrm{~cm}$ x $76 \mathrm{~cm})$ respectivamente, pero las dos difieren mucho en otras características técnicas. La túnica del fardo está confeccionada de dos piezas del telar en un ligamento llano con cara de urdimbre y utilizando hilos de algodón, según el estilo de las túnicas Inca provincial (Fig. 9). Se ha logrado el diseño casana a través de un teñido en reserva que utiliza un tinte semi-fugitivo, el cual se destiñó cuando la túnica doblada empapó la humedad de la tumba. La mancha está centrada a lo largo de un doblez horizontal, oscureciendo parcialmente el diseño casana. Se supone que el diseño fue realizado por un especialista diestro y capacitado en la técnica del teñido en reserva.

Mientras que las túnicas en tapiz que llevan el diseño casana pudieron ser tejidas por un especialista masculino conocido como cumbicamayoc, la túnica del fardo de Rinconada Alta parece haber sido producida en un taller costeño por especialistas que conocían el teñido en reserva sobre algodón. La torsión de los hilos de la urdimbre es S-2Z, lo que parece indicar que fue fabricada en la Costa Norte, donde los hilos de algodón eran torcidos a menudo en la dirección S en un huso sostenido horizontalmente.

John Murra (1962; 1980) ha recopilado de las crónicas unas informaciones sobre las diversas situaciones en que el Imperio Inca hacía fabricar, recoger y distribuir los textiles. Las prendas estandarizadas producidas tanto por los campesinos como por los especialistas (cumbicamayoc) habrán sido recogidas por una red de centros regionales, almacenadas en depósitos imperiales y distribuidas a los vecinos de varias zonas del imperio. Dada la escala imperial de la fabricación, traslado y distribución de los textiles, la relación entre el artesano y el usuario de las prendas estandarizadas era impersonal y muchas veces distanciada. Ofrecer una túnica con un diseño estandarizado como la casana estaba en el derecho imperial. Un provinciano lo habrá considerado un honor al recibir una túnica de diseño Inca.

En la crónica de Guaman Poma, los hombres que usan túnicas con un diseño casana como el que está dibujado en la túnica de Maita Capac (2002 [1615]: 98) también llevan cascos de guerra y cargan armas y escudos (2002 [1615]:149, 159, 196, 254). Los cuatro cuadrados concéntricos del diseño casana de sus túnicas se destacan sobre el cuadrado de fondo, pudiendo ser realizados en dos colores, tal como en las túnicas existentes ya citadas. Las personas que usan estas túnicas y llevan armas incluyen a un monarca, a varios nobles y a un plebeyo (12). Al parecer el diseño casana atravesaba las diversas categorías de rango, tal como el servicio militar.

(12) Un dibujo del Inca Tupac Yupanqui de la crónica de Martín de Murúa (Zuidema, 1991: fig. 9a) muestra al Inca que lleva un casco de guerra y una túnica con una variante del diseño casana. Zuidema analiza el diseño casana. 
Algunos autores, sobretodo J. Rowe (1979: 261), Zuidema (1991: 170-1), y Mujica Pinilla (2002: 29), no han distinguido entre las representaciones de los diseños casana de Guaman Poma, los cuales pueden ser realizados en dos colores y aquellos diseños con cuadrados que tienen que ser realizados en tres colores o más. Ellos agrupan los diseños con bandas verticales u horizontales entre pares de cuadrados concéntricos y/o los con un marco ancho alrededor de los cuatro cuadrados. Los contornos esbozados por Guaman Poma no representan colores, pero sí representan los límites de cada zona de color. Cualquier zona contigua que comparte un perfil tiene que ser de un color contrastante, de acuerdo con su costumbre de dibujar. Un diseño de cuatro colores será percibido de una forma diferente de un diseño de dos colores. Según la disposición y el contraste de ciertos colores, las diferentes zonas de los diseños de tres, cuatro o cinco colores irían a dominar el diseño y presentarían una configuración distinta.

Todas las representaciones del diseño casana en Guaman Poma que pueden ser realizadas en dos colores muestran a hombres en su papel de guerrero, es decir, con casco de guerra, escudos y armas. Sus representaciones de túnicas con diseños que incluyen cuadrados concéntricos, pero que requieren tres colores o más, no son imágenes de guerreros (2002[1615]: 252, 258, 279, 283, 346, 354, 767, 818, 1163). La correlación total entre el diseño casana de dos colores y los guerreros en las ilustraciones de Guaman Poma es un fuerte indicio de que el hombre con la túnica casana de dos colores enterrado en Rinconada Alta habría servido también como soldado. Al parecer, la asociación entre el servicio militar y el diseño casana continuó durante la época colonial. Un ejemplo colonial de una túnica casana bicolor se encuentra en un kero del siglo diecisiete (Cummins, 1998: Fig. 35). El kero muestra también a un hombre que lleva un escudo y una porra estrellada.

Los diseños que exigen más de dos colores no son lo mismo, a pesar de que pueden tener una relación con los diseños casana bicolores, sea en un nivel muy general o sea en un nivel inferior. Ciertas variantes que requieren más de dos colores están agrupadas en varios contextos no militares (por ejemplo, en el rompimiento ritual de la tierra y en la hechicería). Un examen más detallado de las variantes podría llevar a una mayor comprensión de los diseños, los cuales podrían tener relación con el diseño casana usado por los hombres en los contextos militares.

Los ejemplos de diseños casana tanto enteros como fragmentarios que se han encontrado hasta ahora en los museos son del tipo bicolor, como lo es el ejemplo de Rinconada Alta. Por lo visto era el tipo más común. Las túnicas casana varían bastante en su calidad y en el trabajo requerido para fabricarlas. Además de la túnica de algodón teñida en reserva descrita aquí, y las túnicas en tapiz ya referidas, hay otros fragmentos de túnicas casana en los museos, por ejemplo fragmentos de una túnica emplumada, piezas confeccionadas en tapiz y una túnica confeccionada con la técnica de urdimbres discontinuas, todas con diseños casana. El diseño siempre queda representado en dos colores, con cuadrados concéntricos que se destacan contra el fondo cuadrado. Las combinaciones adicionales de dos colores incluyen el azul/marrón y el naranja/crema.

Si bien Guaman Poma indica que las túnicas casana son apropiadas para el papel de guerrero, sobretodo para el líder en una batalla, las diferencias de calidad, evidentes en las túnicas arqueológicas, podrían señalar diferencias de prestigio. Costó menos 
trabajo fabricar la túnica de teñido en reserva de lo que costó fabricar las versiones en tapiz. Aquella fue hecha de materiales menos valiosos que la túnica emplumada, siendo tal vez la recompensa apropiada otorgada a un plebeyo por servir con una unidad pequeña o en un encuentro menos crítico.

El soldado plebeyo representado en Guaman Poma (2002[1615]:196) que carga armas y lleva una túnica casana, evoca analogías con el hombre de Rinconada Alta. Los paños que cuelgan por debajo del casco podrían representar los paños de un tocado de plumas, según se indicó anteriormente. Su descripción del "indio tributario" y "valiente mozo" tal vez podría ser pertinente al hombre de Rinconada Alta, quien fue enterrado con sus hondas, su túnica casana y su tocado de plumas.

A diferencia de la túnica casana y la túnica Inca provincial, el tercer ejemplar de vestuario entre las prendas de vestir del paquete no muestra influencias Inca. El taparrabo de algodón (ofrenda 13d) es estrecho en el centro y más ancho en ambos extremos. Esta forma particular se encuentra mucho entre los taparrabos provenientes de sitios cercanos a Lima como Rinconada Alta, Puruchuco, Armatambo, Pachacamac y Santa Cruz. Algunos taparrabos procedentes de estos sitios tienen diseños en brocado, es decir creados por tramas suplementarias discontinuas en el paño frontal (13). Osborne (1950) publica algunos ejemplos del sitio que ella llama Ate, que a lo mejor son del distrito de Puruchuco. Otros publicados por ella son procedentes de sitios sureños, tan alejados como el valle de Chincha. Que yo sepa, ningún taparrabo de esta forma ha sido atribuido a sitios ubicados al norte del río Chillón.

El taparrabo está confeccionado en ligamento llano de dos piezas de telar, las cuales tienen un largo de alrededor de $75 \mathrm{~cm}$. Está tejido con finos hilos de algodón hilados en S y empleados sencillos. La marcada torsión de los hilos produce una tela elástica. La forma inusitada de las piezas fue producida en el telar al cambiar la densidad y tensión de los hilos de la trama. En cada extremo de la pieza las hileras fueron muy apretadas, pero en el centro quedaron más apartadas. En las secciones del centro de la prenda, la trama fue estirada con mayor tensión para hacer más estrecha la tela.

El hilado y la tejedura son conformes con lo que se conoce de los útiles y técnicas de la Costa Central pues allá hilaban con delgados husos puntiagudos en ambos extremos, los cuales llevaban un tortero en forma de cuenta cerca del centro. El hilo podía ser hilado desde cualquier extremo del huso. Los husos podían ser usados verticales para hacer hilos con torsión en $\mathrm{Z}$, u horizontales para obtener hilos con torsión en S. La marcada torsión de los hilos torcidos en S indica que se sujetaba el huso horizontal y que el hilo torcido saliá desde el extremo opuesto al que se giraba rápidamente con los dedos. Muchos husos de este tipo han sido registrados en los costureros de Rinconada Alta.

La forma acampanada de la tela concuerda también con el tipo de telar utilizado en la Costa Central. Un telar de cintura, en el que el tejedor puede ajustar fácilmente la cantidad de tensión en las urdimbres al cambiar la posición del cuerpo, conviene muy

(13) A veces estas tramas quedan colocadas en la misma calada que la de la tela base; otras veces están colocadas en otra calada de modo que parecen flotar sobre la superficie de la tela encima de una mayor cantidad de urdimbres. 
bien para cambiar la densidad de las tramas y el ancho de la tela. Parece probable que los taparrabos de este tipo fueran producidos en la misma zona donde se usaban, tal vez por las unidades domésticas, y posiblemente por los miembros de una familia.

Tanto la forma como la elasticidad de la tela contribuyen a la manera en que el taparrabo se llevaba puesto. El hombre del fardo vestía un taparrabo parecido (elemento 14), el cual demuestra perfectamente la manera de usarlo. Las esquinas anchas de la parte trasera del taparrabo fueron atadas en la cintura, siendo ceñidas alrededor de esta y anudadas en la delantera. La sección más estrecha pasaba por entre las piernas, y el otro extremo ensanchado y libre pasaba por debajo de las esquinas anudadas formando así una especie de faldilla o delantal por delante — una forma cómoda y modesta de vestir un taparrabo elástico y medio transparente-.

Además de las prendas de vestir descritas, el paquete de la capa 4 contenía un bulto de tela con fibras, hilos, y varias bolsas con hojas (Fig. 11). El pequeño paño envolvente (ofrenda 13e) es una sola pieza de tela de algodón de aproximadamente $28 \mathrm{~cm}$ cuadrados, cuyos orillos terminales llevan un diseño hecho con tramas amarillas, rojas y marrones de lana de alpaca. Las dos esquinas opuestas del paño fueron anudadas para sujetar parcialmente el contenido. Algunas figuras pequeñas están pintadas y bordadas sobre la tela, la cual tiene una técnica y diseño típicos de la costa, si bien el uso de urdimbres pareadas hiladas en $\mathrm{S}$ indica que fue tejida por alguien de la Costa Norte (Chimú) según el estudio de A. Rowe (1984), y no por un tejedor de la Costa Central.

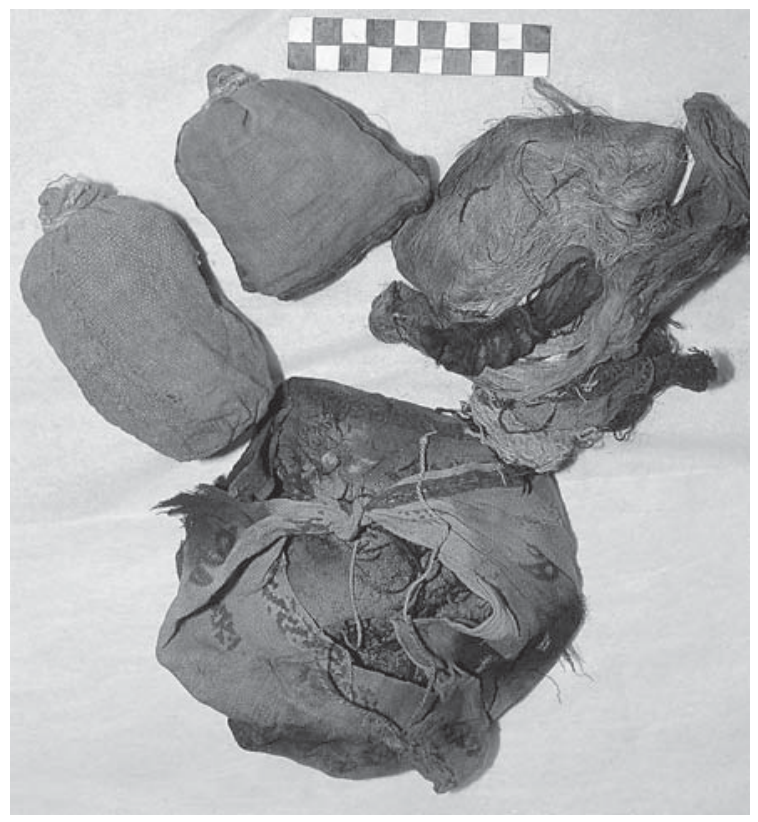

Fig. 11 - Un pequeño atado (ofrenda 13e) dentro del paquete de ropa (ofrenda 13) contenía bolsitas de hojas y las fibras e hilos usados en las hondas del difunto. 
Dentro del paquete había un bulto de fibra vegetal sin hilar, posiblemente furcraea, de colores rojo-marrón, canela y negro, y algunas madejas pequeñas de hilo de camélido, de colores amarillo, dorado, negro y rojo (ofrendas $13 \mathrm{e} 3$ y 13e4). Las fibras e hilos corresponden muy bien al material usado para hacer las tres hondas esmeradamente trabajadas, las cuales se encontraron sobre el pecho del difunto (ofrendas 20a, b y c). La presencia de hondas trenzadas y de materiales sin hilar utilizados para fabricarlas indica que el hombre mismo las confeccionó, y que fue enterrado con los materiales que necesitaba para hacer otras. Hoy día el trenzado de las hondas sigue siendo una actividad textil masculina en los Andes (Cahlander et al., 1980; Zorn, 1982); estas son utilizadas en la cacería, el arreo, las batallas simuladas (tinku) y danzas. Las hondas también fueron utilizadas en la guerra Inca, tal como se observa en numerosas imágenes de guerreros en la crónica ilustrada de Guaman Poma.

Dos bolsas, con un largo de $10 \mathrm{~cm}$ y $12 \mathrm{~cm}$, estaban incluidas también en el bulto anudado (ofrendas $13 \mathrm{e} 1$ y 13e2). Ambas fueron tejidas a partir de una pieza de algodón de color canela, la cual fue doblada y cosida a lo largo de los orillos laterales (Fig. 11). Estaban rellenas de hojas, siendo atadas en la abertura. Una de las bolsas (13e1) había sido embellecida con un ribete de colores cosido a lo largo de los lados y de la base. El tipo de punto utilizado para sujetar el ribete y la presencia de barras de colores repetidos recuerdan el tratamiento dado a los bordes de las túnicas de tapiz estandarizadas y a las bolsas (chuspa). Otra bolsa más, rellena del mismo modo con hojas y atada en la abertura, (ofrenda 13f), fue hallada al exterior del bulto anudado pero dentro de la tela envolvente más grande con las prendas de vestir (ofrenda 13). De las tres bolsas ya enumeradas una mostraba el rasgo norteño (Chimú) de emplear urdimbres pareadas hiladas en S (A. Rowe, 1984), lo que no se nota en las otras dos bolsas.

A lo mejor las bolsas contenían hojas de coca. A veces bolsas de algodón parecidas con la abertura cerrada están cubiertas con juncos y redes (Uhle, 1991[1903]: 38 y Lám. 7, fig. 18; A. Rowe, 1997, fig. 50), o con plumas (A. Rowe, 1997: fig. 49; Schmidt, 1929: 529). Las bolsas con hojas han sido reportadas o ilustradas en entierros costeños de hombres y/o mujeres en Pachacamac (Uhle, 1991[1903]) y HuaqueronesPuruchuco (Cock, 2002: 85-86), así como en los entierros de niños en las alturas (ver A. Rowe, 1997: nota 139).

El tamaño y los adornos de las bolsas varían. Estas habrán sido otro premio imperial otorgado por los incas a los individuos dignos de recibirlas, según una escala de tamaños cuidadosamente clasificados. El hombre de Rinconada Alta poseía tres bolsas de reducido tamaño y no más que una estaba decorada. Como la dirección de la torsión de los hilos de algodón cambia según la bolsa, esto indica que las bolsas encontradas en el fardo podrían haber sido tejidas en regiones distintas, y redistribuidas desde depósitos centralizados. Las bolsas con hojas de coca hacen suponer que el hombre de Rinconada Alta había ganado algún favor con los incas.

Una sustancia granular gris (ofrenda 13g) estaba esparcida por dentro de la tela envolvente. Los gránulos, que tienen el aspecto de conchas quemadas, habrán tenido que ver con la práctica de masticar hojas de coca. La cal es una sustancia que libera el estimulante de las hojas; a veces está elaborada de conchas quemadas. Además en las diferentes capas del fardo se encontraron dos pequeñas calabazas con tapones, los cuales eran caleros, o frascos para cal, según se supone (ofrendas 8 y 16c). 
El paquete grande de la capa 4 junto con su contenido parecen corresponder a artículos personales y muy apreciados del dueño. Estaban empaquetados como para un viaje dentro de una tela cuidadosamente doblada (Fig. 8). Las dos túnicas de mayor prestigio, un taparrabo adicional, material para hacer sus hondas, y las bolsas de coca fueron esmeradamente dispuestas, tal vez por un miembro de su familia. La manera de empaquetar estos objetos en el ritual mortuorio podría reflejar una creencia en la transformación del difunto en ancestro viviente. Cobo hace referencia a las creencias incaicas sobre la vida después de la muerte y a los rituales mortuorios que acompañaban el entierro (1990[1653]: 19-21; 250-52), lo cual indica que se pensaba que los muertos realizaban un largo viaje desde el espacio/tiempo del reino de los vivos, hacia otro reino donde continuaban la vida como antepasados.

Un elemento final de la cuarta capa del fardo es otra tela envolvente (elemento 8) que podría haber sido un manto (Fig. 5b). Al igual que la tela envolvente de la tercera capa, esta consiste también en un tejido de tres piezas, cuyas medidas, textura y diseño reflejan su fabricación en la costa. El tejido de algodón presenta listas de color canela y marrón y en los orillos laterales tiene listas que hacen contraste con esos colores. Las listas del borde muestran un diseño de rombos tejidos por urdimbres flotantes y divergentes (A. Rowe, 1977: 63), flanqueados por unos hilos azules y negros.

El cuerpo fue colocado diagonalmente sobre la tela envolvente y las esquinas opuestas fueron dobladas de un lado al otro del cuerpo. La tela fue más o menos lo bastante larga para cubrir las rodillas encorvadas y las espinillas —una hilera de puntadas toscas apenas sujetaba los bordes de la tela en esta zona-. La esquina en la cabeza del difunto fue doblada y otras puntadas aseguraron los bordes traslapados de la tela. Al retirarse la tela envolvente, quedó expuesta una nueva capa del fardo que mostraba el cuerpo vestido.

\section{CAPA 5 DEL FARDO}

El hombre vestía una túnica llana y sus brazos descubiertos habían sido colocados cruzados en el pecho, el izquierdo encima del derecho. En el pecho se encontró un cuchillo de hoja curva, cubierto con sales metálicas y verdosas, con el mango junto a la mano izquierda. Tres hondas trenzadas le cubrían el torso de un lado al otro, con la paleta en el hombro derecho. Una bolsa (chuspa) esmeradamente tejida estaba colocada sobre cada hombro. Una almohadilla de fibras de algodón procesado cubría su rostro por completo, y otro paño le cubría la parte inferior del cuerpo y las piernas (Fig. 12). Unos instrumentos largos de madera de tamaños diferentes fueron colocados al lado derecho e izquierdo del cuerpo. Al retirar el primer paño de la parte inferior del cuerpo, la mayor parte de la ropa quedó expuesta.

La tela que cubría la parte inferior del cuerpo y las piernas (elemento 9, Fig. 5c) era otra de tres piezas, igual en el ligamento y la textura a los tejidos envolventes de las otras capas (Fig. 5a, b). El tamaño es más reducido que el de los otros tejidos envolventes, pero la construcción es parecida.. Los dos bordes exteriores llevan listas contrastantes con un diseño de pequeños cuadrados. La pieza central del tejido también tenía listas con el mismo diseño. Todos los tejidos envolventes compuestos de tres piezas estaban enteros cuando fueron puestos en el fardo. Como hemos indicado, 


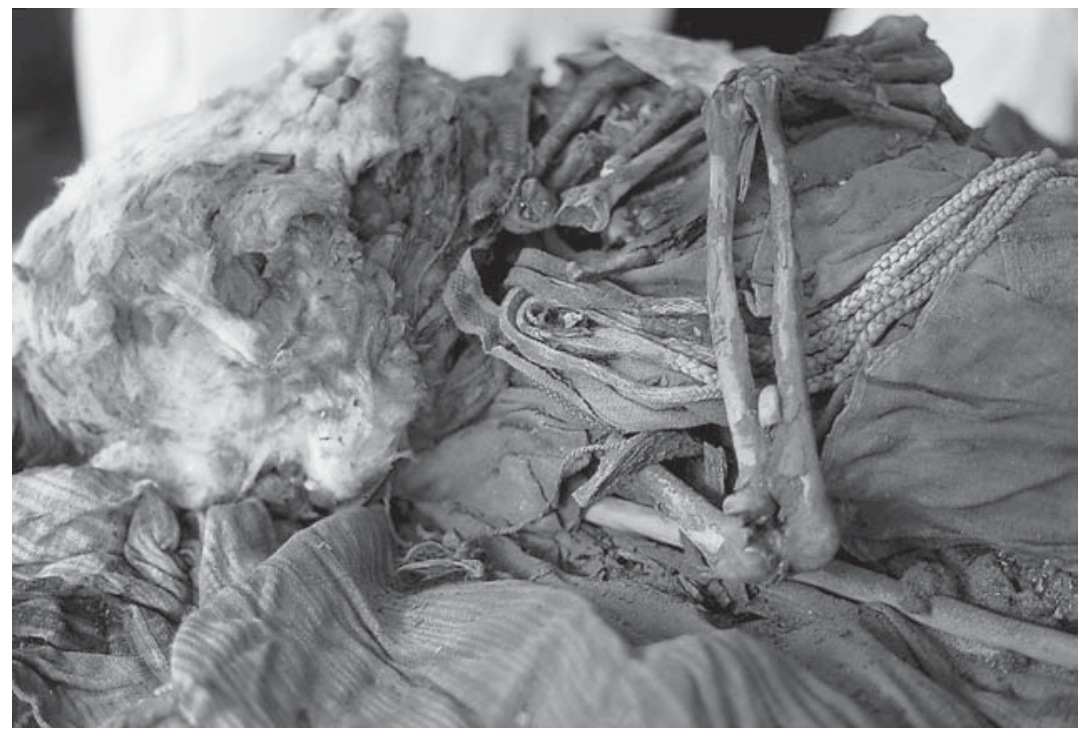

Fig. 12 - Un cuchillo tumi (ofrenda 18, arriba al centro) y tres hondas finas (ofrendas 20a, b, y c) descansan sobre el pecho del difunto en la capa 5. Un acolchado de fibra de algodón le cubre el rostro.

podrían haber sido mantos usados por los costeños durante la vida, siendo reutilizados como mortajas en el entierro. Unos mantos de estilo costeño fueron encontrados junto a túnicas Inca y de influencia Inca en dos fardos de Pachacamac excavados por Uhle (1991[1903]: 37 - 39; A. Rowe, 1997: 33). Los mantos de estilo costeño difieren de los mantos Inca para hombre. Los mantos de estilo Inca están confeccionados con dos piezas de tela que que muestran una textura más densa (A. Rowe, 1997: 26-28; Katterman, 2005: Tabla 4 y figura 11), pero son bastante raros en la Costa Central.

A medida que se retiraba este tejido, se hizo evidente que otro tejido estaba metido a lo largo del lado izquierdo del cuerpo, parcialmente pegado a la pierna. Con paciencia, fue posible retirar una túnica entera (elemento 10) que medía $91 \mathrm{~cm}$ x $75 \mathrm{~cm}$ (Fig. 13). Esta túnica llana tiene las proporciones y medidas que caen dentro de la gama de las túnicas en tapiz Inca (Julien, 1999: tabla 1) las cuales están tejidas de una sola pieza. A diferencia de las túnicas en tapiz, esta túnica está compuesta de dos piezas de telar, y está tejida con hilos de algodón en ligamento llano, cara de urdimbre. El color, la textura y la sencillez de la túnica indican que es del tipo de túnicas Inca costeño confeccionadas para cumplir con la obligación de la mit'a (14) y redistribuidas a la población bajo la norma Inca de la reciprocidad. El hombre del fardo usaba una túnica semejante (elemento 13).

(14) Katterman (2005) describe una variante del tipo de la túnica llana de algodón, que proviene de la quebrada de la Vaca en el valle de Chala. Ella presenta informaciones y dibujos de dieciocho túnicas de algodón que fueron tejidas de una sola pieza. Parece que las túnicas llanas producidas en la costa, supuestamente bajo la obligación de la mit'a para con los incas, pueden haber sido tejidas en uno o dos piezas de telar, quizás según la zona de producción. 

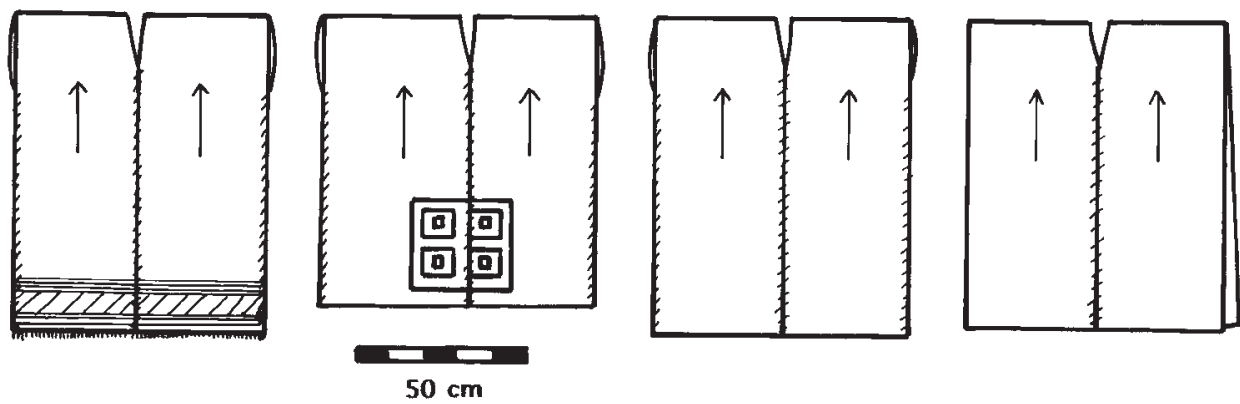

Fig. 13 - Las cuatro túnicas en el fardo tienen las proporciones de las túnicas Inca. Las túnicas llanas a la derecha (elementos 10 y 13) son el tipo de tributo más corriente entre las prendas de vestir que se conservan en la costa.

La capa 5 también incluye dos implementos largos de madera en ambos lados del cuerpo. En el lado izquierdo, extendido desde el codo hasta el talón, se encontró un implemento finamente alisado con un extremo aplanado y ahusado (elemento 11). Tiene $62 \mathrm{~cm}$ de largo y un diámetro máximo de $3,5 \mathrm{~cm}$. El implemento presenta un extremo con una sección transversal redondeada, mientras que el otro extremo es aplanado, con la forma de una espada (15). Al lado derecho del cuerpo se halló un palo delgado que estaba roto en uno de los extremos y tenía el otro ahusado. Tiene un largo de $86 \mathrm{~cm} \mathrm{y}$ un diámetro de $1,8 \mathrm{~cm}$, pero estas medidas no indican el uso original. Parece que estos implementos de madera ayudaban a mantener erecto al torso dentro del fardo; para este mismo propósito habrían servido los palos atados al fardo que recuperamos en la capa tres (elementos 5 y 6).

En los hombros del hombre de Rinconada Alta fueron encontradas dos bolsas tejidas con esmero (ofrendas 16 y 19); alguien había atado juntas las asas de las bolsas cerca del pecho para que permanecieran en su sitio. Las bolsas con listas verticales fueron tejidas con hilos de camélido; las dos tienen ribetes de colores que se parecen a los ribetes cosidos a las túnicas Inca en tapiz. Estos rasgos reflejan las bolsas de estilo Inca recuperadas en muchas zonas costeñas, las cuales, según A. Rowe, corresponden a los acostumbrados regalos diplomáticos (1997: 30-31; 36). Una bolsa parecida estaba incluida en el fardo de un hombre con una porra procedente de Huaquerones-Puruchuco (Cook, 2002), y varios ejemplares fueron recuperados de los entierros humildes de Rinconada Alta. Las dos bolsas del fardo de Rinconada Alta aquí tratadas contenían varios objetos como pinzas, un peine, un frasco para cal, conchas, hojas y semillas.

Además de los diseños de ajedrez y de zigzags en algunas listas, y de los diseños en el asa, la bolsa del lado izquierdo del difunto (Ofrenda 16 y Fig. 14) presentaba un rasgo interesante. Una cara estaba tejida con hilos teñidos de colores rojo y amarillo, mientras la otra cara estaba tejida con los tonos naturales de la fibra de camélido. Las

(15) Cobo (1990: 218) describe un arma de madera llamada macana, la cual era manejada como si fuera un sable. Está descrita con dos bordes afilados y con una empuñadura redondeada. 


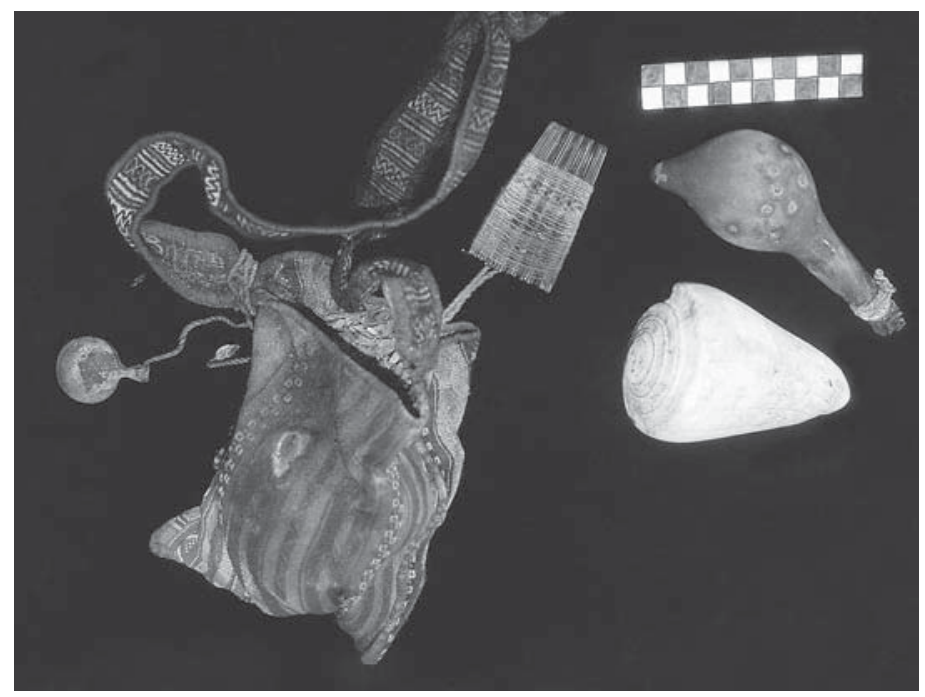

Fig. 14 - La bolsa tejida al lado izquierdo del hombre (ofrenda 16) contenía un peine, pinzas, calero de mate, concha espiral, hojas, y una cuenta de spondylus.

bolsas Inca existentes incluyen ejemplares hechos enteramente con hilos teñidos y otros que están confeccionados enteramente con hilos sin teñir (ofrenda 19). Uno podría pensar que el teñir o el no teñir de los hilos de los regalos diplomáticos reflejaba una escala de prestigio. Una posición intermedia en esta escala la ocuparía la bolsa con la mitad teñida y la mitad sin teñir (ofrenda 16), y otras como ella (Cahlander \& Baizerman, 1985: Fig. 4-1) (16). Se ha informado sobre una pequeña cantidad de bolsas de tapiz teñidas y con diseños, las cuales a lo mejor corresponden a las más prestigiosas de todas las chuspas (A. Rowe, 1997: Fig. 48; Schmidt, 1929: 480).

A través de los colores, la técnica y/o los diseños, la chuspa podría haber señalado la categoría o las hazañas del destinatario. La crónica ilustrada de Guaman Poma (2002[1615]) indica la predilección Inca por la organización jerárquica y por manifestar las jerarquías mediante el uso de la indumentaria y los accesorios. El cronista explica gráficamente las diversas categorías a través de detalles en los vestidos y el arreglo personal; por ejemplo mediante el uso de orejeras, peinados, y adornos de la cabeza y la decoración de las túnicas.

Se solía llevar la coca y la cal para el uso personal en una bolsa de estas medidas. Sin embargo, las dos bolsas del fardo contienen muchos otros tipos de objetos. Atadas

(16) Es razonable esta hipotesis, cuando se tiene en cuenta el trabajo adicional ocasionado por el teñido, así como la comunicación potencial evidenciada en el uso sistemático de colores. Hace mucho tiempo que se supone que las túnicas Inca de colores muy vivos, las cuales son también las más finamente tejidas, son las túnicas de mayor estatus. El estatus inferior de los textiles sin teñir queda indicado por el uso de colores mayormente naturales en las prendas de vestir que fueron producidas para el tributo común en la costa y también por lo tosco que solían ser. 
por una cuerda al asa de una bolsa había una pinza y una cuenta de concha spondylus en forma de una luna creciente (ofrenda 16b). La pinza consistía en un par de placas redondas y convexas, unidas por una estrecha tira doblada de metal. La pinza muestra una coloración verde grisácea, la cual indica que había sido hecha de una aleación de cobre. Se han recuperado pinzas Inca hechas en diferentes formas y de diversos materiales en los entierros de hombres y de mujeres en Huaquerones-Puruchuco (Cock 2002: 89) y Machu Picchu (Salazar \& Burger, 2004: Fig. 130, 132), entre otros sitios.

En el apartado de la crónica de Guaman Poma que trata la vida post-conquista del Perú, el cronista ilustra a cuatro hombres que llevan pinzas atadas al asa de la bolsa tejida de la misma forma que se ve aquí (2002[1615]: 767, 769, 818, 879). Uno es un alcalde, dos son supervisores (mandoncillos) de cinco o diez tributarios, y uno es un plebeyo (indio), a quien se le ve compartiendo la coca. Ninguno de los dibujos de Guaman Poma de la vida pre-conquista muestra a hombres que llevan pinzas amarradas al asa de una bolsa. A pesar de que no podemos estar seguros de que Guaman Poma hacía referencia a cierta práctica de los plebeyos provincianos durante la época colonial, las ilustraciones abren la posibilidad de que la vida del hombre de Rinconada Alta podría haberse extendido más allá de la época Inca (17).

Otro objeto hallado en la bolsa fue una pequeña calabaza con un tapón de madera tallada (ofrenda 16c). Este hallazgo apoya la hipotesis de que la vida del hombre podría haberse extendido hasta la época post-conquista. La calabaza está decorada con incrustaciones circulares de un metal gris. La incrustación de plomo o estaño es una técnica usada para decorar algunos vasos (keros), después de agujerear la madera del vaso para recibir los metales. J. Rowe (1961: 326-329) considera que esta técnica es post-conquista, ya que aparece junto con la técnica de laca en la decoración de los keros, la cual fue comúnmente utilizada en el periodo post-conquista.

El tapón de madera de la calabaza está tallado con dos felinos, colocados cabeza con cola. Una cuerda de algodón está atada alrededor de la boca de la calabaza para ajustar el tapón. Las calabazas pequeñas con un tapón separado se suelen considerar caleros, o frascos para cal, que se usaban para llevar la sustancia caliza consumida con las hojas de coca. La bolsa también contiene una cantidad de fragmentos de hojas (ofrenda 16f), las cuales parecen ser hojas de coca.

Otro artículo de uso personal en la bolsa es un pequeño peine (ofrenda 16e), que consiste en espinas de madera suaves, atadas juntas con hilos de algodón. Este pequeño peine está cuidadosamente fabricado; en la sección central dos púas negras alternan con dos púas de color marrón rojizo. Un peine parecido pero con una secuencia diferente de púas rojas y negras fue encontrado en el fardo de un hombre enterrado en el sitio cercano de Huaquerones-Puruchuco (Cock, 2002: 89).

La bolsa también contiene una concha blanca en espiral (ofrenda 16d) con una punta muy afilada y el otro extremo plano. La concha será un conus fergusoni; tiene $10,5 \mathrm{~cm}$ de largo y 7,5 cm de diámetro. La segunda bolsa del difunto, la que se encontró

(17) Los textiles Inca recuperados de la chulpa de quebrada de la Vaca (Katterman, 2005) abarcan los últimos años de la ocupación Inca y los años tempranos de la Colonia, según se nota por el hallazgo de cuatro cuentas de vidrio azul en uno de los entierros. 
al lado derecho, también contiene conchas, pero son dos valvas de spondylus. Ninguna de estas conchas se encuentra en las aguas de la costa peruana, pues ambas proceden de las aguas más calientes del Ecuador. Las valvas de spondylus son muy numerosas en las tumbas de la época Inca de Rinconada Alta, pero no se encuentran en Armatambo, donde las tradiciones regionales parecen ser más fuertes, incluso durante la época Inca.

Las conchas aparecen como ofrendas en contextos funerarios en muchas partes del Perú en épocas que se remontan por lo menos a 1000 a.C. Se suele suponer que tienen una relación con la fertilidad por su asociación con el agua (Pillsbury, 1996; Davidson 1982). El contraste entre un bivalvo y una concha en espiral en el fardo refleja una oposición de gran antigüedad. Al supuesto "Dios sonriente", esculpido en piedra en el sitio de Chavín de Huantar se le ve sujetando una valva de spondylus en una mano y un strombus en la otra; el Obelisco Tello también representa conchas de spondylus y strombus (J. Rowe, 1967). El contraste entre la concha en espiral colocada en la bolsa del lado izquierdo del hombre y las valvas de un molusco que posee una simetría de reflejo exacto en la bolsa del lado derecho podría reflejar creencias muy antiguas respecto a la eficacia de las conchas y la relación entre ellas. Conchas de Spondylus y de conus fergusonii también aparecen juntas en el ritual mortuorio de la Costa Norte, tanto en entierros Chimú (Montoya Vera, 1996) como en entierros Moche de alto estatus en Sipán (Alva \& Donnan, 1993).

Cuando la bolsa (ofrenda 16) fue retirada del cuerpo, llamó la atención una pequeña cuenta de color turquesa que estaba escondida entre los dobleces de la túnica del guerrero (ofrenda 17). La cuenta de piedra turquesa a lo mejor es de malaquita, siendo pequeña y de forma cilíndrica con un hueco perforado. No se encontraron otras cuentas de piedra.

La bolsa tejida al lado derecho (ofrenda 19) estaba también llena de muchos objetos. La bolsa está tejida en tonos naturales de fibras de camélido, los cuales están dispuestos de una manera simétrica en siete bandas verticales (Fig. 15). En el centro de cada banda hay una lista estrecha con diseños. Estas listas también flanquean las bandas. El diseño sencillo de estas listas no presenta más que barras horizontales o puntitos, los cuales surgen directamente del tipo de ligamento del tejido a través del orden por el cual los colores son alternados. El tejedor no tuvo que hacer ningún recojo manual de los hilos para producir el diseño. Tanto la ausencia de hilos teñidos como la ausencia de diseños que necesitaban un manejo manual de los hilos indican que esta bolsa tenía un valor más reducido como regalo diplomático de lo que tenía la bolsa del lado izquierdo del hombre, cuya mitad estaba confeccionada de hilos teñidos. La bolsa está rematada con un punto especial que tiene el aspecto de pequeñas barras de colores a lo largo del borde. Este punto realizado sobre el borde es típico del remate de las túnicas de tapiz Inca. Se llama punto anillado tricotado cruzado y los colores de los hilos alternan de una manera rítmica, siendo teñidos de rojo, amarillo, negro, marrón y dorado. La larga asa de la bolsa está tejida en ligamento llano con cara de urdimbre y muestra una banda de puntitos marrones sobre un fondo negro en el centro.

Había una espina puntiaguda de 4,8 cm de largo (ofrenda 19d) atada al asa de la bolsa por medio de un cordón de fibra vegetal. No está claro cómo se empleaba la espina. Quizás servía para el arreglo personal como las pinzas y el peine. Como fue constatado 


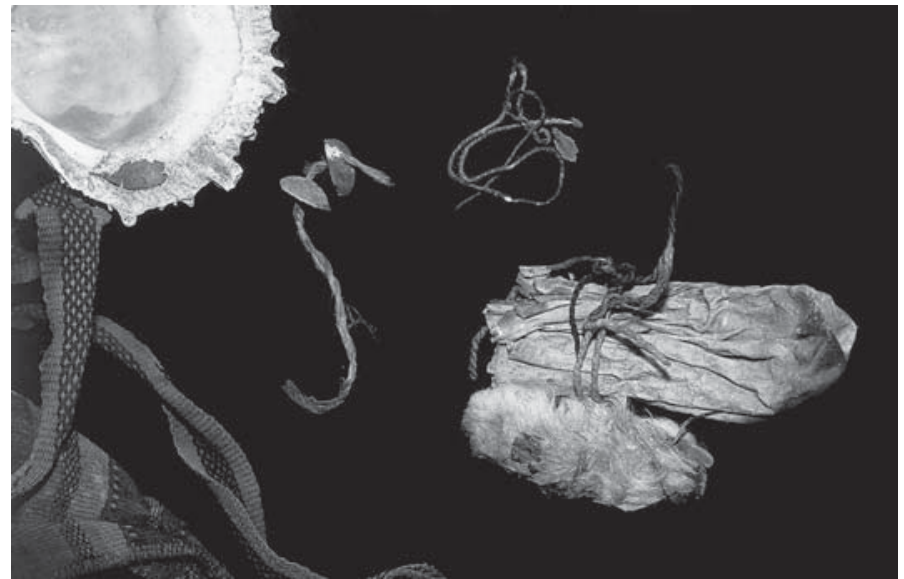

Fig. 15 - La bolsa al lado derecho (ofrenda 19) contenía hojas, valvas de spondylus, semillas ensartadas (nectandra), un pedazo de piel amarilla, y una bolsita de cuero.

anteriormente, la bolsa contenía dos valvas de spondylus. Una es más grande (ofrenda 19b) que la otra (ofrenda 19c), lo que indica que formaban un par desigual. Ambas tienen los labios de un color anaranjado rosáceo en el lado de adentro y las típicas escamas puntiagudas en la parte de afuera. Dos semillas (ofrenda 19e) estaban ensartadas en el cordón de fibra vegetal. Serán los cotiledones de la nectandra. Towle (1961: Lámina IV8) publica un hallazgo idéntico dentro de una canasta del cementerio de Chancay. Hay referencias a collares hechos de los cotiledones perforados de la nectandra encontrados en los sitios de la Costa Central de Pachacamac, Chuquitanta, y Ancón (Towle, 1961: 40), e ilustrados con un fardo excavado en Huaquerones-Puruchuco (Cock, 2002: 8586). Collares parecidos de nectandra han sido encontrados también en entierros de la Costa Norte (Montoya Vera, 1996: 205-207). Un hilo corto de algodón (10 cm) y fragmentos de hojas secas, posiblemente de la coca, se encontraron también en la bolsa (ofrendas 19f y 19g).

Los últimos de los artículos hallados dentro de la bolsa estaban atados juntos. Era una bolsita de cuero (ofrenda 19h.1) que estaba atada a una pequeña tira de piel amarillenta 19h.2). La bolsita de cuero contiene una sustancia granular que puede ser un pigmento mineral. La piel amarilla puede ser de un cuy. Se encuentran cuyes enteros o trozos de ellos en contextos funerarios de esta época y otras más tempranas (Cock, 2002: 85-86; Reiss \& Stübel, 1888: vol. 3, pl. 119-2; Schmidt, 1929: 561-1, -2).

En efecto las dos bolsas tejidas del fardo contenían numerosos artículos. Sería aventurado suponer que el contenido de las bolsas o incluso del fardo son simplemente efectos personales. A lo mejor estos objetos tienen otro significado relativo a las costumbres funerarias. Un indicio que ayuda a descifrar este otro significado reside en las formas en que los objetos están arreglados —en pares desiguales_- en lados o extremos opuestos del cuerpo. La variedad de los materiales con que se fabricaron las ofrendas - metal, concha, fibras vegetales, fibras de camélido, semillas, hojas, piel, cuero- podría repetir conceptos significativos y relaciones que eran apropiadas en 
contextos funerarios. Las ofrendas de concha, coca, maíz rojo y cuy se repiten en fardos durante épocas largas y a través de una gran distancia, lo que indica que formaban parte de una red amplia de creencias y rituales pertinentes a los muertos. Sería fácil pasar por alto el significado de las ofrendas, como los "masticados" (ofrendas 1 y 7) y los pequeños paquetes de fibra vegetal sin hilar (ofrenda 11 y 12), pero estas están colocadas en formas que sugieren acciones rituales, es decir, a la cabeza y a los pies del difunto.

Los otros artículos en la Capa 5 del fardo incluyen tres hondas trenzadas con cuidado (ofrendas 20a, b y c). Las tres hondas se destacan, estando colocadas a través del torso, con las paletas de las hondas al lado del hombro derecho. Además de ser bien fabricadas, las tres hondas se parecen en tamaño, fabricación y materiales (Fig. 12). Las hondas fueron trenzadas de largas fibras vegetales, a lo mejor de furcraea, y llevan un poco de decoración hecha de fibras de camélido de varios colores. La paleta consiste en fuertes soportes laterales espesos. El espacio entre los soportes consiste en una malla en forma de rombo que está fabricada de algunas trenzas finas. El proyectil de piedra, que había de ser colocada en la malla, habrá tenido el tamaño de un huevo de gallina, para poder ser sostenido por una malla tan grande.

A pesar de que las hondas se encuentran a menudo entre los restos arqueológicos de la costa durante muchas épocas, todavía no se ha publicado un estudio detallado de sus contextos. Las representaciones en cerámica de épocas más tempranas demuestran que las hondas servían a veces para tocados, además del uso presunto en la caza, pastoreo, baile y guerra. El tamaño, la esmerada calidad y la uniformidad de las tres hondas en el fardo, y el hecho de que se destacan sobre el torso, indican que la identidad del hombre de Rinconada Alta está muy ligada a ellas. La presencia de materiales sin trabajar para hacer otras hondas de este tipo dentro del paquete envuelto con telas (ofrendas 11, 12,13e.3, y 13e.4) repite su identificación con estas tres hermosas hondas durante esta vida y en la siguiente. Otra honda más pequeña y más sencilla, hecha de fibras vegetales más bastas, estaba adherida a la parte superior del brazo debajo de su túnica (ofrenda 22). La diferencia cualitativa entre las tres hondas bien fabricadas, dispuestas sobre el torso y la honda doblada y anudada adherida al brazo indica que los dos tipos servían para propósitos diferentes. Mientras la honda más pequeña y sencilla podrá haber sido empleada en la cacería o pastoreo, las tres hondas más grandes parecen ser apropiadas para la guerra.

Cobo afirma que los soldados empleaban hondas hechas de lana o de cabuya (una fibra vegetal, posiblemente furcraea), la cual es muy fuerte, según dice (1990[1653]: Bk. 14, ch. 9, 215-219). Los guerreros que peleaban con hondas eran los primeros en entrar en batalla, lanzando sus piedras desde lejos.

El tipo de malla, fabricada de fibras vegetales largas y duraderas, y los espacios entre las trenzas indican que tres de las cuatro hondas del fardo eran apropiadas para lanzar grandes piedras, como se había de esperar de las armas usadas en la guerra. También los elementos y ofrendas del fardo son todos uniformes lo que sugiere que el hombre de Rinconada Alta habría servido, a veces, como soldado en el ejército del Inca. Está acompañado de prendas de vestir y accesorios, tales como la túnica casana y el tocado de plumas, los cuales están asociados con guerreros que comandaban unas tropas en la batalla (Guaman Poma, 2002[1615]). Asimismo, tenía una cantidad de regalos 
diplomáticos del tipo de los recibidos por los plebeyos en situaciones como el servicio militar, es decir, bolsas con coca, chuspas y túnicas llanas.

Aunque el servicio militar no era la única circunstancia que dio lugar al otorgamiento de regalos diplomáticos, se podría mantener con bastante razón que era la ruta más común por la cual un provinciano podía llamar la atención favorable de la administración Inca. El servicio militar era también la vía principal para que los plebeyos mejorasen su categoría social (J. Rowe, 1947: 279-80). El hombre de Rinconada Alta fue enterrado con una túnica Inca provincial, lo que sugiere que había alcanzado al menos un nivel humilde entre las varias categorías sociales de la burocracia provincial. Él no tiene las orejas perforadas de la nobleza, ni lleva los metales preciosos, textiles muy decorados, ni banquillo de madera (tiyana), todo lo cual podría indicar que pertenecía a la pequeña nobleza de administradores provinciales llamados kuracas (Menzel, 1977: 8-18). Es más probable que haya alcanzado el nivel de mayoral de un pequeño grupo de tributarios, como los mandoncillos de la época Colonial (Guaman Poma 2002[1615]: 767, 769). El contenido del fardo indica un distinguido servicio militar y una categoría social regular y esto refleja la práctica Inca de recompensar el valor militar con el ascenso social.

El último artículo en la capa 5 del fardo es un cuchillo en forma de T (tumi), otro objeto que podría indicar tanto un nivel de categoría social como un destacado servicio militar. El cuchillo estaba dispuesto sobre el pecho del difunto de la misma manera que las tres hondas. La hoja delgada y curvada $(4,5 \mathrm{~cm})$ está afilada y tiene un mango en el centro del borde superior (Fig. 12). La parte superior del mango tiene un agujero, lo que sugiere que el cuchillo podía estar suspendido de un cordón alrededor del cuello. La hoja curvada y el mango están hechos de una sola lámina de metal y los depósitos de color verde grisáceo indican que el cuchillo está hecho de una aleación rica en cobre, probablemente el bronce de cobre y estaño que se solía emplear durante la época Inca. (Lechtman, 1979:16). El mango delgado está cubierto por dos pedazos de caña que están unidos al mango por cordones. Algunos de los cordones pasan a través de una perforación en la unión del mango y hoja, la cual sujeta los cordones y la caña que cubre el mango. Unas huellas de una sustancia negra y resinosa quedan en la base del mango. Hay informaciones sobre cuchillos Inca parecidos que se han encontrado desde el Ecuador hasta el Chile. Algunos tienen un remate más decorado (Salazar \& Burger, 2004:191-3 y Fig. 154).

Aunque los cuchillos tumi podían haber sido empleados en rituales y llevados como una señal de la categoría social, una imagen de Guaman Poma (2002[1615]:163) indica que los cuchillos eran también usados por capitanes del ejército que servían bajo los órdenes del Inca. El fiero Rumiñahui, con un hacha de batalla al lado, emplea el cuchillo para cortarle el estómago a su víctima, el Inga Illescas, que está colgado con la cabeza para abajo. Guaman Poma cuenta que Rumiñahui hizo un tambor de la piel del Inca, una copa para beber de la cabeza y una flauta de los huesos. Estas son acciones que también requieren de un cuchillo. Se cree con toda razón que algunos soldados llevaban o empleaban los cuchillos, además del arma de pelea que era su especialidad. A lo mejor el gobierno desempeñaba un papel en la producción y distribución de los cuchillos tumi (Salazar \& Burger, 2004: 192). Los cuchillos más sencillos, como el del fardo de 
Rinconada Alta, parecen ser de un tipo estandarizado y habrán sido otorgados con mayor frecuencia que los cuchillos muy decorados con un remate de pequeñas figuras.

Unas herramientas para trabajar metales han sido descubiertas en varios contextos de Rinconada Alta, lo que indica que el trabajo con metales era el oficio de algunas personas que vivían en el sitio y estaban sepultadas allí. Algunos instrumentos fueron encontrados en bolsas tejidas enterradas con individuos mientras que otros quizás eran ofrendas enterradas en los edificios. Carcedo de Mufarech y Vetter Parodi (2002) proponen que los orfebres, sin ser Incas, fabricaban objetos de metal usando las técnicas y aleaciones Inca, quizás como mita o tributo al Inca. El cuchillo del guerrero pudo haber sido fabricado en esta zona o igualmente pudo haber sido fabricado en otra parte del imperio. Es difícil, quizá imposible, determinar donde un objeto estandarizado fue fabricado porque la producción y redistribución de los bienes hechos por mitimaes según las pautas establecidas por los Incas tenían lugar en muchas regiones del imperio.

Al cuchillo tumi se le da un lugar de honor sobre el pecho del hombre vestido. Junto con sus tres hondas esmeradamente trenzadas, el cuchillo parece haber sido un bien muy importante, el cual estaba muy vinculado a su identidad y/o logros.

\section{CAPA 6 DEL FARDO}

La última capa del fardo consiste en objetos en contacto directo con el cuerpo del hombre (Fig. 16). Estaba vestido con una túnica y un taparrabo, del mismo tipo que los que se encontraron como ofrendas en las capas exteriores del fardo.

La túnica llana que usaba (elemento 13) es parecida a la túnica colocada a lo largo del costado izquierdo (elemento 10), sino que las costuras laterales no están cosidas

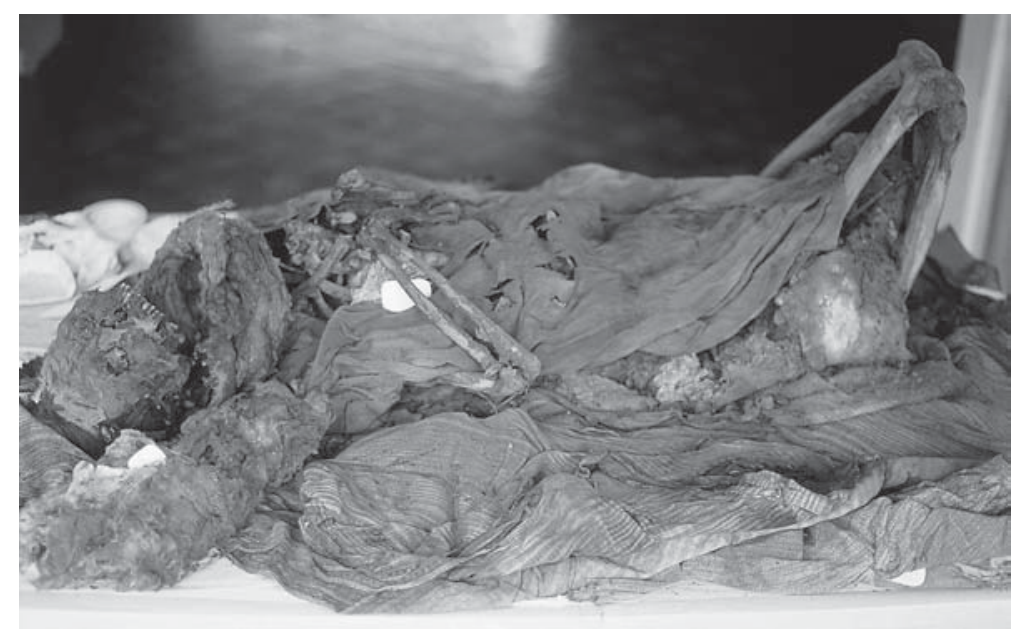

Fig. 16 - El difunto usaba una túnica sin coser (elemento 13) y un taparrabo (elemento 14). El cuerpo fue acomodado de rodillas y las manos y los brazos fueron cruzados sobre el pecho, la mano izquierda sobre la derecha. Un collar de fibra de algodón muy sólido le rodeaba el cuello. 
(Fig. 13). La túnica de algodón es de color marrón claro y está tejida en un ligamento llano con cara de urdimbre.

Las proporciones y medidas $(87$ x $74 \mathrm{~cm})$ concuerdan con las pautas marcadas por los incas, pero la túnica está tejida en dos piezas de telar y cosida en el centro. Es parecida a otras túnicas llanas de Pachacamac (Uhle, 1990: 37-9) y Chincha (Garaventa, 1977). Las dos túnicas llanas del fardo pertenecen al tipo más común entre las túnicas estandarizadas de algodón, aunque en la Costa Sur, las túnicas llanas de algodón con proporciones Inca están confeccionadas a veces de una sola pieza (Katterman, 2002; 2005). Las túnicas llanas de calidad regular eran distribuidas de los almacenes Inca a los provincianos en varias ocasiones según la necesidad o como una recompensa. Cuando el Inca presidía una serie de ritos de matrimonio en las provincias, a las parejas se les regalaban dos juegos de ropa (Betanzos, 1996[1551-1557]: 57; 63). A los soldados también se les regalaba la ropa, que solía consistir en dos prendas por turno de pelea, de acuerdo con la generalización hecha por Murra, quien se basó en varias crónicas (1986: 52).

El taparrabo de algodón que usaba el difunto (elemento 14) es típico de los taparrabos de la Costa Central y Sur. Como fue descrito antes, tiene un faldón delantero de forma acampanada que cuelga hacia delante como un mandil. La única decoración sobre el taparrabo marrón claro son unas cuantas hileras de hilos azul y marrón que funcionaban como las cuerdas de extremidad. Las cuerdas de extremidad de colores se encuentran a menudo en los fragmentos de taparrabos de Rinconada Alta y Armatambo, como también se encuentran los hilos torcidos en S. Se midió el taparrabo que se había puesto rigido a fin de encontrar la medida de la cintura del difunto. Esta medía $75 \mathrm{~cm}$, lo que indica que el hombre tenía una complexión delgada.

Su cara estaba completamente cubierta por un acolchado espeso de algodón (elemento 15). A las fibras se les habían retirado las semillas, y luego habían sido peinadas para estirarlas. Alrededor del cuello llevaba un collar en forma de un anillo sólido de fibras estiradas y comprimidas (elemento 15). El anillo, que tenía un diámetro de 20 a $22 \mathrm{~cm}$, parece haber funcionado como un refuerzo del cuello para mantener derecha la cabeza. Está unido de forma espiral con un cordón hilado de fibras vegetales. Como no había ningún corte en el anillo, parece que fue hecho in situ por los que preparaban el cuerpo para el entierro. Cuando se retiró el acolchado de algodón de la cara, apareció una placa rectangular de metal de 2,00 x 0,80 cm, la cual estaba adherida al lado inferior del acolchado (ofrenda 23). El color de la placa y los depósitos sobre ella indican que en la aleación predomina la plata con un poco de cobre. Unos depósitos de sales metálicas sobre los dientes del difunto muestran que la placa había sido colocada en la boca.

El colocar una lámina de metal dentro de la boca del muerto era una costumbre mortuoria muy difundida en el antiguo Perú. Las láminas de metal colocadas en la boca de los muertos tenían la forma de un disco en los entierros Incae Ychsma de Armatambo, y en los entierros tardíos en el sitio de Macas en el Valle del Chillón (c.p. Daniel Guerrero Zevallos).

Hay razones para creer que el tipo de metal correspondía a la categoría del individuo, por lo menos en esta época, porque el derecho de usar objetos de oro era un privilegio otorgado por el gobierno imperial Inca. La nobleza costeña era enterrada con 
una cantidad de vasijas y ornamentos de oro, tal como ocurrió con los llamados "nobles de oro" excavados por Uhle en Ica Viejo, y descritos por Menzel (1977: 8-18). Los cuerpos recuperados en un mausoleo de quebrada de la Vaca Oeste (Katterman, 2002; 2005) llevaban escamas de oro sobre las órbitas de los ojos. Es posible que la aleación de la placa colocada en la boca del hombre de Rinconada Alta sea de plata y cobre, lo que indica que su categoría social era bastante humilde en comparación con la de los nobles.

Otra ofrenda de spondylus fue colocada encima del pecho del hombre, debajo de la túnica que usaba (ofrenda 21). Otras tres valvas (ofrendas 9,19 b y c) estaban incluidas en su atado. Ofrendas de valvas de spondylus fueron encontradas en muchos entierros de la época Inca en Rinconada Alta, así como en sitios cercanos (Cock, 2002: 85-85). Al parecer, el uso del spondylus estaba menos restringido que antes, puesto que los entierros Ychsma con spondylus en Armatambo suelen estar asociados con individuos de un estatus más alto. La cantidad de spondylus en los entierros en Rinconada Alta puede indicar que la gente recibía las conchas como un pago simbólico por los servicios prestados a través de una red estatal de distribución. Los Spondylus trabajados podrían haber llevado un mayor prestigio, como el collar con colgantes de spondylus que acompañaba a un joven con orejeras doradas enterrado en Ica Viejo durante esta época (Menzel, 1977: 12-13).

Una cuarta honda (ofrenda 22) se encontró adherida a la parte superior del brazo derecho del difunto. La honda era más sencilla, burda y pequeña que las otras tres hondas (ofrendas 20a, b, y c), habiendo sido doblada dos veces por la mitad y atada con un nudo flojo. La calidad y el tamaño de esta honda contrastaban con los de las otras tres (ofrenda 20a, b y c), lo que indica que podría haber servido para un propósito diferente, quizás para cazar aves y la caza menor.

La mitad inferior del fardo estaba en malas condiciones en esta capa, sin duda por la descomposición del cuerpo. Sin embargo, un pedazo grande de un mate redondo (lagenaria) fue retirado del lado derecho del cuerpo en la zona de las nalgas (elemento 17). A juzgar por la parte intacta, parece que el hombre podría haber estado sentado sobre el mate con las pantorrillas metidas debajo de él. En los entierros Ychsma en Armatambo, Daniel Guerrero Zevallos ha observado que los cuerpos o fardos estaban colocados algunas veces sobre mates grandes con cenizas dentro, lo que podría indicar que el uso del mate era una práctica regional. Es posible que soguillas de fibras vegetales pudieran haber atado el mate al cuerpo. Inicialmente estas soguillas daban varias vueltas para amarrar la cavidad estomacal, pero estaban sueltas cuando tuvo lugar el desenfardelamiento. Fragmentos desiguales de cuatro paños (elemento 18) rellenaban el espacio entre los muslos y las pantorrillas de sus piernas que estaban muy flexionadas.

El mate, las soguillas y las telas de relleno sugieren que el cuerpo del hombre fue colocado en una postura determinada para el entierro. Las rodillas muy flexionadas y el torso erecto indican una postura arrodillada, con las pantorrillas y los pies metidos debajo de él. La colocación de palos de madera o implementos a cada costado del cuerpo (elementos 5, 6, 11, y 12) en dos capas diferentes del fardo sugiere que los que preparaban el fardo querían mantener el torso erecto. El collar sólido de algodón que le rodeaba el cuello (elemento 15) también indica un intento de mantener la cabeza 
levantada. Aunque el cuerpo podía haber estado echado durante las varias etapas del enfardelamiento y de la colocación de ofrendas, al final el fardo debió quedar erecto, lo cual le devolvió al cuerpo su postura arrodillada.

Si bien una postura arrodillada no es muy corriente, el cuerpo de otro fardo procedente del sitio cercano de Huaquerones-Puruchuco muestra una postura semejante (Cock, 2002: 85-86, 88-89). Cock señala que el cuerpo tenía las rodillas dobladas como si estuviera arrodillado y los dedos de los pies extendidas como los de un bailarín. La ilustración muestra que el torso se mantenía casi erecto. Los brazos de los dos hombres estaban acomodados de una forma parecida sobre el pecho, con la mano izquierda sobre la derecha. Hay bastantes semejanzas en la construcción y el contenido de los dos fardos, muchos de los cuales ya han sido mencionados anteriormente. Quizás las semejanzas de mayor importancia, además de la postura, son la presencia de textiles y armas Inca o de influencia Inca. El hombre de Rinconada Alta poseía tres hondas grandes mientras que el otro hombre poseía una porra en forma de estrella. Al describir la guerra Inca, Cobo (1990[1653]: 215-219) se refiere a escuadrones de militares provincianos que peleaban con armas diferentes (hondas, flechas y arcos, lanzas y dardos, bolos, picas, porras, hachas de guerra), los cuales estaban encabezados por su propio teniente, quien a su vez estaba bajo el mando de un comandante de linaje Inca. La postura poco corriente que estaba compartida por los hombres de los dos fardos puede reflejar su rol como soldado en el ejército Inca, pero hará falta cotejar otros ejemplos con estos si hemos de confirmar esta suposición.

\section{CONCLUSIONES}

Avances en la investigación de textiles Inca e Inca-provincial (Julien, 1999; Katterman \& Riddell, 1994; Katterman, 2002; 2005; Menzel, 1977; A. Rowe, 1978; 1984; 1992; 1997; J. Rowe, 1979; Zuidema, 1991) nos proporcionan una base para identificar con mayor seguridad las prendas de vestir de esta época. Las crónicas españolas describen las prácticas Inca relativas a la manufactura y distribución de tejidos en las provincias, y varios etnohistoriadores han sopesado y sintetizado las informaciones sobre la producción textil Inca a partir de las fuentes coloniales (Murra, 1962; 1980; 1986; J. Rowe, 1947; 1979; Uhle, 1991[1903]). Ahora las informaciones etnohistóricas pueden ser vinculadas más precisamente con los textiles arqueológicos de la época Inca porque hay mejores datos sobre los tipos de prendas de vestir. El fardo de Rinconada Alta abunda en restos de indumentaria y en accesorios textiles y brinda la oportunidad de examinar el conjunto de textiles asociados con un individuo (Fig. 17) a la luz de los estudios etnohistóricos y arqueológicos. Así llega a ser posible plantear unas hipótesis más detalladas y más precisas acerca de las hazañas y el estatus de un hombre enterrado en Rinconada Alta durante el Incanato.

El hombre de Rinconada Alta fue enterrado con textiles y ofrendas que reflejan la vida de un provinciano que consiguió el favor de los Incas. Su fardo contiene el tipo de regalos diplomáticos (bolsas de hojas de coca, chuspas, un cuchillo tumi y túnicas llanas) que podrían haber sido otorgadas a un plebeyo de provincia. Son recompensas de gran significado pero no de la mejor calidad. Unas comparaciones con otros entierros del Incanato en la costa muestran unas diferencias sútiles en la calidad y en los materiales 

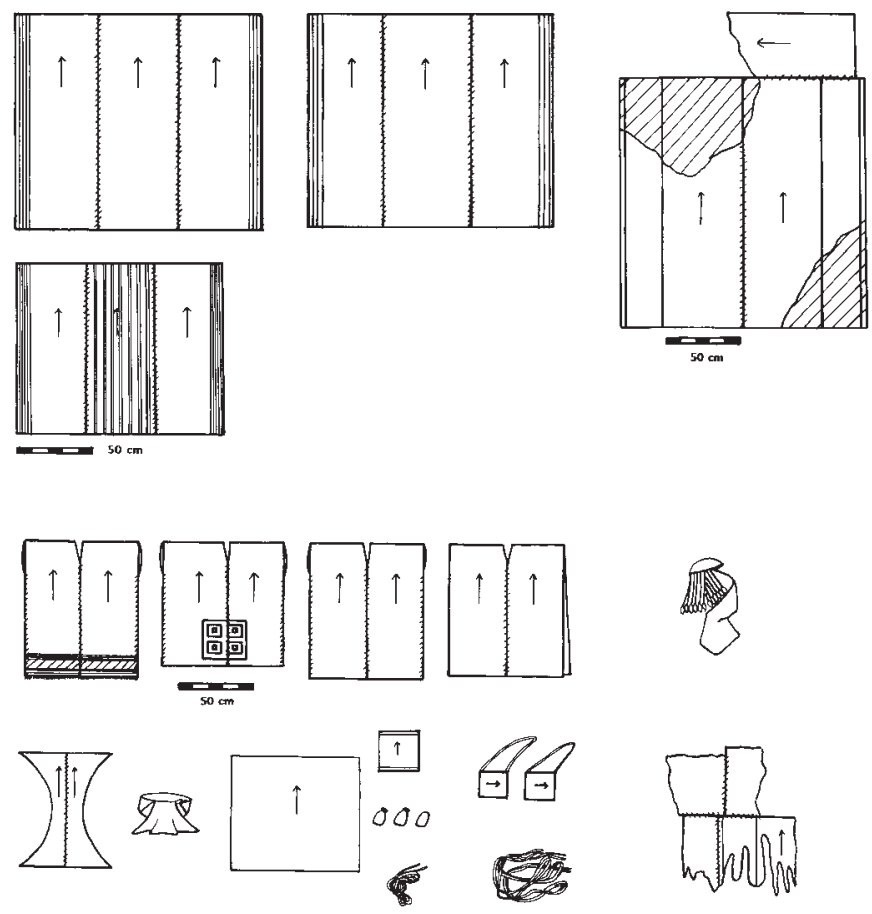

Fig. 17 - El conjunto de textiles en el fardo incluye tipos de mantos y taparrabos costeños, así como chuspas Inca y túnicas de influencia Inca.

de los regalos diplomáticos Inca (Cock, 2002; Katterman, 2002; 2005; Menzel, 1977; Uhle, 1991[1903]). El fardo también incluye señales de que nuestro provinciano podría haber servido en el ejército Inca. Sobresale el hecho de que tiene tres hondas hermosas, una túnica con el diseño casana y un tocado de plumas con paño trasero, un conjunto de tres artículos que Guaman Poma asocia con los soldados Inca de todas las clases (2002[1615]: 98, 149, 159, 196, y 254). Su origen costeño es claro debido al estilo de los taparrabos y mantos en su fardo. Al parecer, a pesar de sus antecedentes poco nobles, ni siendo Inca, él alcanzó un modesto nivel social en la jerarquía Inca. La túnica provincial Inca en el fardo manifiesta que él llegó a ocupar una posición en la jerarquía administrativa de la provincia. Sin embargo, la calidad y cantidad modestas de su indumentaria y la ausencia total de ciertos artículos (orejeras, ornamentos de oro y el banquillo de madera llamado tiyana) indican que su categoría era inferior a la de la nobleza hereditaria provincial (kuracas). Él podría haber sido mayoral de un pequeño grupo de tributarios.

Los incas tenían en gran estima a los plebeyos provincianos que estaban en la edad militar y recompensaban actos de valor militar a través de un sistema complicado de honores militares y recompensas. Si el difunto ganaba sus regalos diplomáticos, tales como la túnica casana estandarizada, por medio de sus hazañas militares, a lo mejor él era hondero. Su tocado de plumas puede señalar que mandaba un cuerpo de honderos 
de su región. Era probable que el modesto estatus social que alcanzó dentro de la burocracia provincial estuviese vinculado a un distinguido servicio militar, porque esta era la ruta principal para el ascenso social, la cual habría estado abierta a un plebeyo de las provincias bajo el Imperio Inca (J. Rowe, 1947: 279-80; Conrad \& Demarest, 1999: 123-125). Como el soldado plebeyo con la túnica casana que fue representado en la crónica de Guaman Poma (2002[1615]: 196), el hombre de Rinconada Alta al parecer contribuyó sustancialmente a los esfuerzos imperiales, y los incas le recompensaron por medio de regalos y un ascenso social a una categoría baja de la burocracia provincial.

\section{Agradecimientos}

A los autores los ayudaron a desenfardelar el envoltorio funerario y a registrar el contenido los arqueólogos Moira Novoa Silva y Santiago Morales Erroch, la conservadora Ángela Pacheco Carrillo, y el dibujante Rafael Luna Bernal. El estudio de los textiles de Rinconada Alta se ha llevado a cabo durante varios años. Quisiéramos agradecer la contribución de Arabel Fernández, Marianne Watson, y Rosa de Noriega. Les agradecemos a los colegas Sergio Barraza y Arabel Fernández quienes nos ofrecieron sus comentarios en el borrador preliminar de este artículo y a la antropóloga forense María Inés Barreto por sus comentarios sobre la fractura cervical del individuo.

La primera autora agradece especialmente el apoyo de la Fundación Selz, que le pagó los gastos del viaje al Perú. Nuestras gracias también a la Sra. Mary Cragg de Landa por su interés en el Proyecto Rinconada Alta y por su hospitalidad en muchas ocasiones.

\section{Referencias Citadas}

ALVA, W. \& DONNAN, C. B., 1993 - Royal Tombs of Sipán, 229p.; Los Angeles: Fowler Museum of Cultural History.

APONTE M., D., 2000 - La vestimenta femenina en la Costa Central del Perú durante el Período Intermedio Tardío. Estudios Atacameños, 20: 91-101; San Pedro de Atacama, Chile.

BETANZOS, J. de, 1996[1551-1557] - Narrative of the Incas; Austin: University of Texas Press. Traducido y editado por R. Hamilton \& D. Buchanan.

BROTHWELL, D. R., 1987 - Desenterrando Huesos, 287p.; México D. F.: Fondo de Cultura Económica.

BROWN, J. A., 1995 - Andean Mortuary Practices in Perspective. In: Tombs for the Living: Andean Mortuary Practices (Tom D. Dillahay, ed.): 391-405; Washington: Dumbarton Oaks.

BUIKSTRA, J. E. \& UBELAKER, D. H. (eds.), 1994 - Standards for Data Collection from Human Skeletal Remains; Fayetteville: Arkansas Archaeological Survey. Arkansas Archaeological Survey Research Series N ${ }^{\circ} 44$.

CAHLANDER, A. \& BAIZERMAN, S., 1985 - Double-Woven Treasures from Old Peru; St. Paul, Minnesota: Dos Tejedoras.

CAHLANDER, A., ZORN, E. \& ROWE, A. P., 1985 - Sling Braiding of the Andes; Boulder: Colorado Fiber Center. Weaver's Journal, Monograph IV. 
CARCEDO DE MUFARECH, P. \& VETTER PARODI, L., 2002 - Instrumentos Utilizados para la Fabricación de Piezas de Metal para el Periodo Inca. Ponencia presentada en el Simposio, "Identidad y Transformación en el Imperio Inka y en los Andes Coloniales: Perspectivas Arqueológicas y Etnohistóricas", 16-18 de agosto, 2002; Lima: Pontificia Universidad Católica del Perú.

COBO, B., 1983[1653] - History of the Inca Empire; Austin and London: University of Texas Press. Traducido y editado por R. Hamilton. Prólogo de J. H. Rowe.

COBO, B., 1990[1653] - Inca Religion and Customs; Austin and London: University of Texas Press. Traducido y editado por R. Hamilton. Prólogo de J. H. Rowe.

CONRAD, G. W. \& DEMAREST, A. A., 1984 - Religion and Empire: The Dynamics of Aztec and Inca Expansionism, 266p.; Cambridge: Cambridge University Press. New Studies in Archaeology.

COCK, G. A., 2002 - Inca Rescue. National Geographic, May 2002: 78-91.

CUMMINS, T., 1998 - Let Me See! Reading Is for Them: Colonial Andean Images and Objects "como es costumbre tener los caciques Señores". In: Native Traditions in the Postconquest World (E.H. Boone \& T. Cummins, eds.): 91-148; Washington, D.C.: Dumbarton Oaks.

DAVIDSON, J., 1982 - Ecology, Art, and Myth: A Natural Approach to Symbolism. In: PreColumbian Art History: Selected Readings (A. Cordy-Collins, ed.): 331-343; Palo Alto: Peek Publications.

EECKHOUT, P., 2002 - Hallazgo y Desenfardelamiento de un Bulto Funerario de Pachacamac, Costa Central del Perú. In: Actas, II Jornadas Internacionales sobre Textiles Precolombinos (V. Solanilla Demestre, ed.): 135-152; Barcelona: Departament d'Art, Universtat Autónoma de Barcelona.

EMERY, I., 1966-The Primary Structures of Fabrics: An Illustrated Classification; Washington: The Textile Museum.

GARAVENTA, D., 1977 - Ancient Textiles with Grave Association from Chincha, Peru. Doctoral Dissertation, Department of Anthropology. University of California; Berkeley.

GUAMAN POMA DE AYALA, F., 2002[1615] - El Primer Nueva Corónica i Buen Gobierno, 3 volúmenes. Versión on line, www.kb.dk/elib./mss/poma.

JULIEN, C. J., 1999 - Spanish Use of Inca Textile Standards. Indiana, 16: 57-81; Berlin.

KATTERMANN, G. L., 2002 - Clothing Styles from a Provincial Inca Outpost. In: Silk Roads, Other Roads; Northampton, Mass.: Textile Society of America. Proceedings of the 8th Biennial Symposium of the Textile Society of America, Sept. 26-28, 2002 held at Smith College.

KATTERMANN, G. L., 2005 - Tela y Técnica entre los Incas Provincianos de la Costa Sur del Perú. In: Tejiendo sueños en el Cono Sur: Textiles Andinos, pasado, presente y futuro (V. Solanilla Demestre, ed.): 261-276; Barcelona: Universitat Autonoma de Barcelona. Actas de 51st Congreso Internacional de Americanistas.

KATTERMAN, G. L. \& RIDDELL, F. A., 1994-A Cache of Inca Textiles from Rodadero, Acarí Valley, Peru. Andean Past, 4: 141-167.

KROGMAN, W. M. \& ISCAN, M. Y.,1986 - The Human Skeleton in Forensic Medicine; Springfield: Charles C. Thomas.

LECHTMAN, H., 1979 - Issues in Andean Metallurgy. In: Pre-Columbian Metallurgy of South America (Elizabeth P. Benson, ed.): 1-40; Washington, D.C.: Dumbarton Oaks.

MENZEL, D., 1977 - The Archaeology of Ancient Peru and the Work of Max Uhle, 135p.; Berkeley, University of California: Robert H. Lowie Museum of Anthropology.

MONTOYA VERA, M., 1996 - Implicaciones del Estudio de Semillas Rituales en la Época Prehispánica. Revista del Museo de Arqueología, Antropología e Historia, 6: 206-219; Trujillo, Perú: Universidad Nacional de Trujillo. 
MUJICA PINILLA, R., 2002 - Arte e identidad: Las raíces culturales del Barroco peruano. In: El Barroco Peruano (R. Mujica Pinilla, P. Duviols, T. Gisbert, R. Samanez Argumedo y M. Concepción García Sáiz, eds.): 1-57; Lima: Banco de Crédito del Perú. Colección Arte y Tesoros del Perú.

MURRA, J., 1962 - Cloth and Its Functions in the Inca State. American Anthropologist, 64(4): 710-728.

MURRA, J., 1980 - The Economic Organization of the Inka State; Greenwish, Conn.: JAI Press. Research in Economic Anthropology.

MURRA, J., 1986 - The expansion of the Inka state: armies, war, and rebellions. In: Anthropological History of Andean Polities (J. Murra, N. Wachtel \& J. Revel, eds): 4958; Cambridge: Cambridge University Press.

OSBORNE, C., 1950 - Shaped Breechcloths from Peru. Anthropological Records, 13(2): 157-184.

PACHACUTI YAMQUI, J. de S. C., 1995 - Relación de Antigüedades de este Reino del Perú, lxxv + 427p.; México: Fondo de Cultura Económica.

PILLSBURY, J., 1996 - The Thorny Oyster and the Origins of Empire: Implications of Recently Uncovered Spondylus Imagery from Chan Chan, Peru. Latin American Antiquity, 7(4): 313-340.

PRÜMERS, H., 1998 - Un Nuevo tipo de camisa del antiguo Perú. Bönner Amerikanistische Studien, 30: 217-237.

RAVINES, R. \& STOTHERT, K., 1976 - Un Entierro común del Horizonte Tardío en la Costa Central del Perú. Revista del Museo Nacional, XLII: 153-205.

REISS, W. \& STÜBEL, A., 1880-1887 - The Necropolis of Ancon in Peru: A Contribution to Our Knowledge of the Culture and Industries of the Empire of the Incas. 3 vols.; Berlin: A. Asher \& Co. Traducido por A. H. Keane.

ROWE, A. P., 1977 - Warp-Patterned Weaves of the Andes. Washington: The Textile Museum.

ROWE, A. P., 1978 - Technical Features of Inca Tapestry Tunics. Textile Museum Journal, 17: $5-28$.

ROWE, A. P., 1984 - Costumes and Featherwork of the Lords of Chimor: Textiles from Peru's North Coast; Washington: The Textile Museum.

ROWE, A.P., 1992 - Provincial Inca Tunics of the South Coast of Peru. Textile Museum Journal, 31: 5-52.

ROWE, A. P., 1997 - Inca Weaving and Costume. Textile Museum Journal, 1995-1996 (1997), vols. 34-35: 4-53.

ROWE, J. H., 1947 - Inca Culture at the Time of the Spanish Conquest. In: Handbook of South American Indians, vol. 2, The Andean Civilizations (J. Steward, ed.): 183-330; Washington: Smithsonian Institution. Bureau of American Ethnology, Bulletin 143.

ROWE, J. H., 1961 - The Chronology of Inca Wooden Cups. In: Essays in Pre-Columbian Art and Archaeology (S.K. Lothrop y otros, eds): 317-341; Cambridge: Harvard University Press.

ROWE, J. H., 1967 - Form and Meaning in Chavin Art. In: Peruvian Archaeology: Selected Readings (J. Rowe \& D. Menzel, eds.): 72-103; Palo Alto: Peek Publications.

ROWE, J. H., 1979 - Standardization in Inca Tapestry Tunics. In: The Junius B. Bird PreColumbian Textile Conference (A. Rowe, E. Benson \& A. Schaffer, eds.): 239-264; Washington, D.C.: The Textile Museum and Dumbarton Oaks. May 19th and 20th, 1973.

SALAZAR, L. C. \& BURGER, R. L., 2004 - Catalogue. In: Machu Picchu: Unveiling the Mystery of the Incas (Richard L. Burger \& Lucy C. Salazar, eds.); New Haven y London: Yale University Press.

SALOMON, F., 1995 - "The Beautiful Grandparents": Andean Ancestor Shrines and Mortuary Ritual as Seen Through Colonial Records. In: Tombs for the Living: Andean Mortuary Practices (T. Dillahay, ed.): 315-353; Washington: Dumbarton Oaks. 
SCHMIDT, M., 1929 - Kunst und Kultur von Peru; Berlin: Propyläen-Verlag. STOTHERT, K., 1979 - Unwrapping an Inca Mummy Bundle. Archaeology, 32(4): 8-17.

STOTHERT, K. \& YARBERRY, E., 1979 - Preparing a Mummy Bundle: Note on a Late Burial from Ancon, Peru. Nawpa Pacha, 16 (1978): 13-22.

SUCHEY, J. M., BROOKS, S. T. \& KATZ, D., 1988-Instructions for Use of the Suchey-Brooks System for Age Determination of the Female Os Pubis. Material instructivo que acompaña a los modelos de los huesos púbicos femeninos del sistema Suchey-Brooks. Distribuido por France Casting (Diane France, 2190 West Drake Road, Suite 259, Fort Collins, Colorado 80526). (Ms.)

TOWLE, M. A., 1961 - The Ethnobotany of Pre-Columbian Peru. Viking Fund Publications in Anthropology, Number 30.

UBELAKER, D. H., 1989 - Human Skeletal Remains. Excavation, Analysis, Interpretation; Washington: Taraxacum. Segunda edición.

UHLE, M., 1991[1903] - Pachacamac: Report of the William Pepper, M.D., LL. D., Peruvian Expedition of 1896. Reprinted from the 1903 edition (Department of Archaeology, University of Pennsylvania, Philadelphia); Philadelphia: University of Pennsylvania. The University Museum of Archaeology and Anthropology.

ZORN, E., 1982 - Sling Braiding in the Macusani Area of Peru. Texile Museum Journal, 19-20 (1980-1981): 41-54.

ZUIDEMA, R. T., 1991 - Guaman Poma and the Art of Empire: Toward an Iconography of Inca Royal Dress. In: Transatlantic Encounters: Europeans and Andeans in the Sixteenth Century (K.J. Andrien \& R. Adorno, eds.): 151-202; Berkeley and Los Angeles: University of California. Century, editado por K.J. Andrien y R. Adorno, pp. 151-202. University of California, Berkeley and Los Angeles. 


\section{ANEXOS}

\section{ANEXO 1}

\section{CAPAS, ELEMENTOS Y OFRENDAS EN EL FARDO 1816-E3, RINCONADA ALTA}

La lista sigue la secuencia del desenfardelamiento del envoltorio funerario, empezando por la capa exterior. El Fardo tiene 6 capas, indicadas en la columna 1. Objetos importantes usados en la construcción del fardo se llaman aquí "elementos". Otros objetos incluidos dentro o entre capas se llaman aquí "ofrendas". Los elementos y las ofrendas están numerados por separado pero en esta lista se ha guardado la posición de cada objeto relativa a los otros. Algunas ofrendas eran paquetes que contenían una cantidad de objetos; en tal caso se han añadido letras minúsculas para indicar su asociación dentro de la misma ofrenda. En un solo caso, un paquete dentro de otro paquete contenía objetos separados. Se ha indicado su asociación a través de una serie número-letra-número. Se han dado las medidas en centímetros. Si no se indica lo contrario el largo precede al ancho. Otras medidas son abreviadas así: diámetro (D); circunferencia (C); altura (A).

\begin{tabular}{|c|c|c|c|c|}
\hline Capa & $\begin{array}{l}\text { Ele- } \\
\text { mento }\end{array}$ & $\begin{array}{l}\text { Ofren- } \\
\text { da }\end{array}$ & Descripción & Dimensiones \\
\hline 1 & 1 & & $\begin{array}{l}\text { fragmentos de soga del envoltorio } \\
\text { exterior, Z-2S }\end{array}$ & D: 0,8 \\
\hline 1 & 2 & & $\begin{array}{l}\text { tela envoltorio; vestido de algodón } \\
\text { más fragmento }\end{array}$ & $209 \times 164$ \\
\hline 2 & 3 & & gruesa capa de fibra de algodón & \\
\hline 2 & & 1 & un masticado, cerca a la cabeza & $3,6 \times 2,5$ \\
\hline 2 & & 2 & pluma, verde; cortada & $3 \times 1,5$ \\
\hline 2 & & 3 & costilla humana & $10,5 \times 0,8$ \\
\hline 2 & & 4 & 3 semillas de mate & $1,6 \times 0,9$ \\
\hline 2 & & 5 & hoja de coca & $4 \times 2$ \\
\hline 2 & & 6 & fragmento de piedra negra & $2 \times 0,5$ \\
\hline 2 & & 7 & un "masticado", cerca a los pies & $4 \times 3$ \\
\hline 2 & & 8 & botella de mate con tapa de algodón & A: $9 ; \mathrm{C}: 21,5$ \\
\hline 2 & & 9 & $\begin{array}{l}\text { valva, spondylus princeps, a los pies del } \\
\text { fardo }\end{array}$ & $9 \times 12,2$ \\
\hline 3 & 4 & & fragmentos de soga, $S-2 Z$ & D: 0,6 \\
\hline 3 & 5 & & palo de madera, ahusado; lado izquierdo & L: $121 ; \mathrm{D}: 3$ \\
\hline 3 & 6 & & palo de madera, ahusado; lado derecho & L: $105 ; \mathrm{D}: 3$ \\
\hline 3 & & 10 & $\begin{array}{l}4 \text { mazorcas de maíz morado; cerca a } \\
\text { la barbilla, lado derecho }\end{array}$ & L. $7,2-12$ \\
\hline 3 & 7 & & tela envoltorio, 3 paños; a cuadros & $147 \times 160$ \\
\hline
\end{tabular}




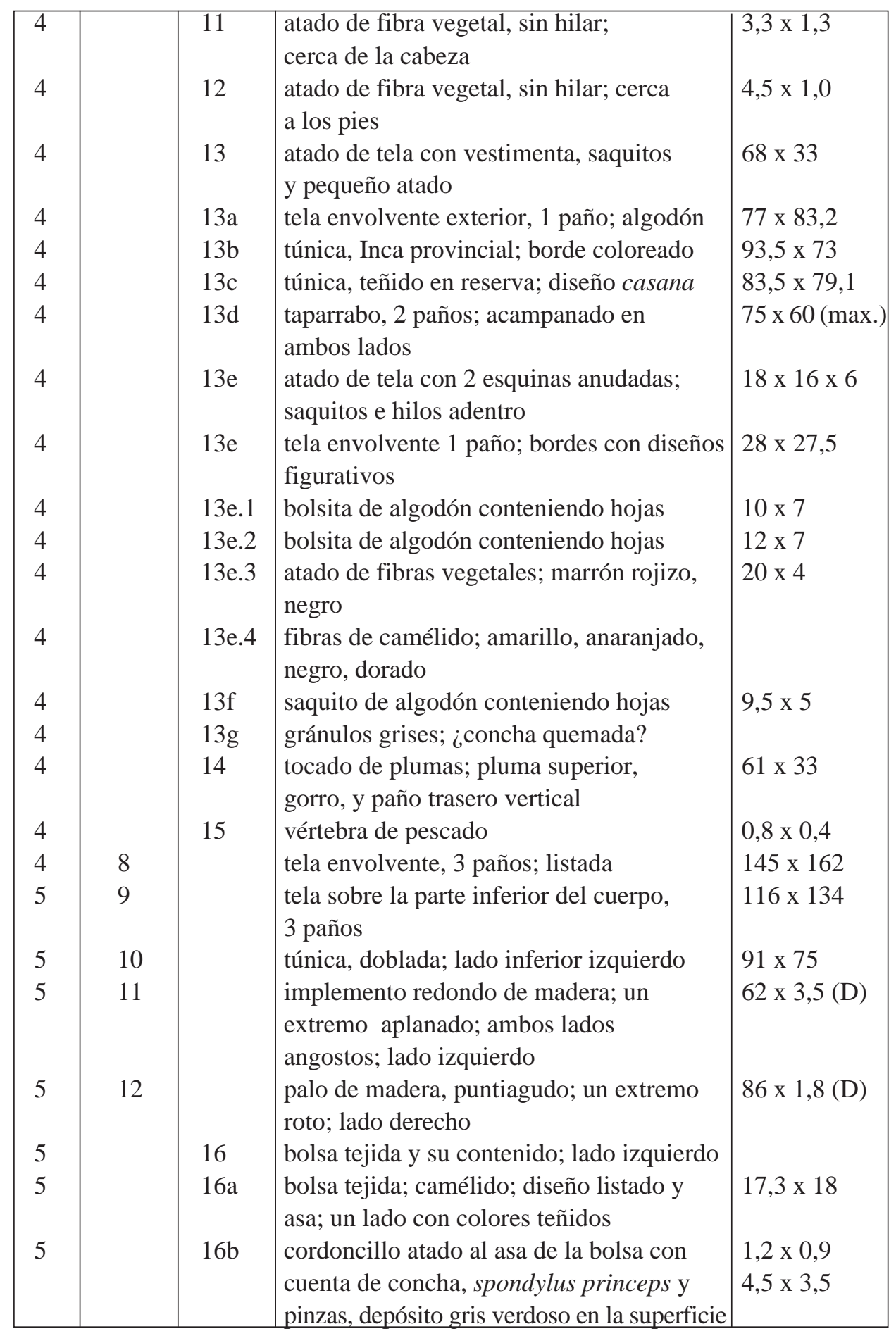




\begin{tabular}{|c|c|c|c|c|}
\hline 5 & & $16 \mathrm{c}$ & $\begin{array}{l}\text { calero de mate con tapón de madera } \\
\text { tallada y metal gris incrustado }\end{array}$ & $13 \times 7,4(\mathrm{D})$ \\
\hline 5 & & $16 \mathrm{~d}$ & $\begin{array}{l}\text { concha blanca y cónica con un final } \\
\text { estrecho }\end{array}$ & $10,5 \times 7,5(\mathrm{D})$ \\
\hline 5 & & $16 \mathrm{e}$ & peine; espinas rojas, negras; hilo envuelto & $7,3 \times 4,2$ \\
\hline 5 & & $16 f$ & fragmentos de hoja sueltos en bolsa; ¿coca? & \\
\hline 5 & & 17 & $\begin{array}{l}\text { cuenta de piedra, cilíndrica; color } \\
\text { turquesa; ¿malaquita? }\end{array}$ & $0,8(\mathrm{D}) \mathrm{x} 0,4(\mathrm{~A})$ \\
\hline 5 & & 18 & $\begin{array}{l}\text { cuchillo tumi, hoja en media luna; sobre } \\
\text { el pecho }\end{array}$ & $13,5 \times 13,5$ \\
\hline 5 & & 19 & bolsa tejida y su contenido; lado derecho & \\
\hline 5 & & $19 \mathrm{a}$ & $\begin{array}{l}\text { bolsa tejida; camélido; listado en colores } \\
\text { naturales; asa }\end{array}$ & $\begin{array}{l}18 \times 19,5 \\
70,5\end{array}$ \\
\hline 5 & & $19 b$ & valva de concha, spondylus princeps & $10 \times 10,8$ \\
\hline 5 & & $19 \mathrm{c}$ & valva de concha, spondylus princeps & $8,2 \times 9$ \\
\hline 5 & & $19 d$ & espina, atada con cordoncillo al asa de la bolsa & $4,8 \times 0,8$ \\
\hline 5 & & $19 \mathrm{e}$ & mitad de semillas en cordoncillo; nectandra sp. & $2 \times 1 ; 2 \times 1$ \\
\hline 5 & & $19 f$ & hilo de algodón, Z-2S & 10 \\
\hline 5 & & $19 \mathrm{~g}$ & fragmentos de hoja sueltos en bolsa; ¿coca? & \\
\hline 5 & & 19h.1 & bolsa de cuero con polvo adentro & $10 \times 4$ \\
\hline 5 & & 19h.2 & pedazo de piel amarilla unida a la bolsa de cuero & $5 \times 3$ \\
\hline 5 & & 20 & 3 hondas; fibra basta, trenzadas; sobre el pecho & \\
\hline 5 & & $20 \mathrm{a}$ & honda; diamantes en fibra de camélido roja & $188(\mathrm{~L})$ \\
\hline 5 & & $20 \mathrm{~b}$ & honda & $184(\mathrm{~L})$ \\
\hline 5 & & $20 \mathrm{c}$ & $\begin{array}{l}\text { honda; pájaros en fibra de camélido roja, } \\
\text { amarilla, negra }\end{array}$ & $192(\mathrm{~L})$ \\
\hline 6 & 13 & & túnica, algodón; sobre el cuerpo & $87 \times 74$ \\
\hline 6 & 14 & & taparrabo, algodón; sobre el cuerpo & N/A \\
\hline 6 & 15 & & $\begin{array}{l}\text { fibra de algodón sobre el rostro, alrededor } \\
\text { del cuello }\end{array}$ & \\
\hline 6 & 16 & & fragmentos de soga, basta; cavidad estomacal & Varios \\
\hline 6 & 17 & & sección de un mate; alrededor de las nalgas & \\
\hline 6 & & 21 & $\begin{array}{l}\text { valva de concha, spondylus princeps; } \\
\text { sobre el pecho }\end{array}$ & \\
\hline 6 & & 22 & $\begin{array}{l}\text { honda; fibra basta, trenzada; parte } \\
\text { superior del brazo derecho }\end{array}$ & Doblada \\
\hline 6 & 18 & & fragmentos de 4 telas cosidas juntas; & 83 x 92 (max.) \\
\hline 6 & & 23 & $\begin{array}{l}\text { placa de metal; deposito gris verdoso; } \\
\text { área de la boca }\end{array}$ & $2 \times 0,8$ \\
\hline
\end{tabular}




\section{ANEXO 2}

\section{EL INDIVIDUO AL INTERIOR DEL FARDO}

El hombre de Rinconada Alta tenía entre 35 y 40 años al momento de morir (Suchey et al., 1988; Iscan \& Loth, 1986, in Ubelaker, 1989: 87-91; Lovejoy et al., 1985, in Buikstra \& Ubelaker eds., 1994: 24-32; Meindl \& Lovejoy, 1985, in Ubelaker, 1989: 83-84; Brothwell, 1987: 108). Su altura estimada es de entre 157 y $160 \mathrm{~cm}$, según las tablas de Genovés para indígenas mexicanos (Genovés, 1967; en Krogman e Iscan, 1986: 319). No presentaba deformación craneana. Su cabello era corto, llegando a la altura de la nuca. Restos de piel y cartílago estaban presentes, sin embargo, se encontraban en proceso de carbonización.

\section{1. Posición del cuerpo}

Los codos estaban moderadamente flexionados, descansando en la parte más baja del pecho y formando un ángulo de aproximadamente $45^{\circ}$. La mano derecha se encontraba semi flexionada y sobre el antebrazoizquierdo. La manoizquierda se hallaba desarticulada, pero pudo haberse situado sobre el húmero derecho. La espalda estaba erecta, los fémures formaban un ángulo de aproximadamente $135^{\circ}$ con la pelvis y uno de $45^{\circ}$ con las tibias, formando una posición "arrodillada”. Los pies estaban desarticulados. Faltaban todos los tarsos, exceptuando uno, así como cuatro falanginas y una falangeta de los pies.

\section{2. Traumatismos}

El hombre presenta una fractura peri mortem entre la primera y quinta vértebra cervical, la cual pudo ser la causa de muerte. Esta fractura más parece haber sido causada por una caída que por un golpe, según la opinión de María Inés Barreto (antropóloga, especialista en Antropología Forense de la Universidad Nacional de Colombia). Una fractura antigua en el extremo distal de una quinta falange de la primera hilera del pie (posiblemente del lado izquierdo, hacia medial), también es evidente.

\section{3. Osteoartritis o artritis degenerativa}

El hombre de Rinconada Alta pudo haber sufrido un gran dolor en el cuello debido a varias lesiones en las vértebras cervicales, las cuales incluyen una erosión considerable en la parte inferior del cuerpo de la sexta cervical y otra en la parte superior de la séptima (amabas hacia ventral), así como erosiones leves en diferentes partes de la primera, tercera, cuarta y quinta cervical, incluyendo al cóndilo izquierdo del occipital. Estas dolencias están relacionadas a la fusión congénita de la quinta y la sexta vértebras cervicales.

La zona sacra-lumbar muestra también una labiación moderada en la lumbar 4 (superior e inferior) y el sacro (parte superior), así como una labiación severa en la lumbar 5 (parte superior), todas ellas hacia la parte ventral. Erosiones moderadas están presentes en el codos (cabeza de radio izquierdo hacia medial y en el derecho, hacia ventral y superior), muñeca izquierda (epífisis distal del radio, hacia medial) y en las 
rodillas (parte dorsal de cóndilos laterales de los fémures). En la mano derecha hay una caries moderada en epífisis distal del primer metacarpo, mayor hacia palmar. Un grado leve de erosiones se observa en el codo derecho (línea divisoria entre tróclea y capitolio del húmero, hacia dorsal y ventral) y en el tobillo izquierdo (epífisis distal del peroné). En la muñeca derecha están presentes dos caries leves (semilunar, en articulación con el piramidal).

\section{4. Signos de estrés}

Hiperostosis porótica curada y cribra orbitalia en proceso de curación están presentes. También son evidentes hipoplasias lineales del esmalte en varios periodos de su vida: desde los 18 meses +/- 6 meses hasta los 5 años +/- 16 meses (con mayor severidad en el último) y a los 12 años +/- 30 meses (Ubelaker, 1989: 64).

\section{5. Salud dental}

No hay evidencias de caries. El desgaste dental es moderado. El grado de sarro es moderado a considerable y está asociado a una resorción alveolar moderada (severa en la zona de los molares, con pérdida ante mortem de los terceros molares derechos). Estas patologías están relacionadas a erosiones leves en las articulaciones témporomandibulares.

Resumiendo, el hombre de Rinconada Alta no muestra señales de violencia interpersonal como fracturas en el cráneo o fracturas defensivas en el antebrazo (fractura de Parry), que son esperables en el caso de guerreros. Su ausencia, sin embargo, no significa que el hombre de Rinconada Alta no lo haya sido. Podría haberse tratado de un guerrero que nunca sufrió aquellas heridas en batalla. Las actividades que realizó durante su vida le causaron un mayor deterioro en el cuello y cintura. La ausencia de caries en los dientes sugeriría un consumo de pocos carbohidratos (tal como maíz). Asimismo, sufrió episodios de estrés de orígenes inciertos durante su niñez, pero parece haber sido una persona saludable en el momento de su muerte, causada posiblemente por una fractura en el cuello debido a una caída. 